\title{
Behaviour of lithium and its isotopes during weathering in the Mackenzie Basin, Canada
}

\author{
Romain Millot (1) ${ }^{*}$, Nathalie Vigier (2) and Jérôme Gaillardet (3) \\ (1) BRGM, Metrology Monitoring Analysis Department, Orléans, France \\ Corresponding author, e-mail: r.millot@brgm.fr \\ (2) CRPG, CNRS, Nancy-Université, Vandœuvre-lès-Nancy, France \\ (3) IPGP, Equipe de Géochimie et Cosmochimie, Université Paris 7, Paris, France
}

\begin{abstract}
We report Li isotopic compositions, for river waters and suspended sediments, of about 40 rivers sampled within the Mackenzie River Basin in northwestern Canada. The aim of this study is to characterize the behaviour of $\mathrm{Li}$ and its isotopes during weathering at the scale of a large mixed lithology basin. The Mackenzie river waters display systematically heavier $\mathrm{Li}$ isotopic compositions relative to source rocks and suspended sediments. The range in $\delta^{7} \mathrm{Li}$ is larger in dissolved load (from +9.3 to $+29.0 \%$ ) compared to suspended sediments (from -1.7 to $+3.2 \%$ ), which are not significantly different from $\delta^{7} \mathrm{Li}$ values in bedrocks. Our study shows that dissolved Li is essentially derived from the weathering of silicates and that its isotopic composition in the dissolved load is inversely correlated with its relative mobility when compared to $\mathrm{Na}$. The highest enrichment of ${ }^{7} \mathrm{Li}$ in the dissolved load is reported when Li is not or poorly incorporated in secondary phases after its release into solution by mineral dissolution. This counterintuitive observation is interpreted by the mixing of water types derived from two different weathering regimes producing different $\mathrm{Li}$ isotopic compositions within the Mackenzie River Basin. The incipient weathering regime characterizing the Rocky Mountains and the Shield areas produces ${ }^{7} \mathrm{Li}$ enrichment in the fluid phase that is most simply explained by the precipitation of oxy-hydroxide phases fractionating Li isotopes. The second weathering regime is found in the lowland area and produces the lower $\delta^{7} \mathrm{Li}$ waters (but still enriched in ${ }^{7} \mathrm{Li}$ compared to bedrocks) and the most Li-depleted waters (compared to $\mathrm{Na}$ ). Fractionation factors suggest that the incorporation of $\mathrm{Li}$ in clay minerals is the mechanism that explains the isotopic composition of the lowland rivers. The correlation of boron and lithium concentrations found in the dissolved load of the Mackenzie rivers suggests that precipitation of clay minerals is favoured by the relatively high residence time of water in groundwater. In the Shield and Rocky mountains, Li isotopes suggest that clay minerals are not forming and that secondary minerals with stronger affinity for ${ }^{7} \mathrm{Li}$ appear.

Although the weathering mechanisms operating in the Mackenzie Basin need to be characterized more precisely, the $\mathrm{Li}$ isotope data reported here clearly show the control of $\mathrm{Li}$ isotopes by the weathering intensity. The spatial diversity of weathering regimes, resulting from a complex combination of factors such as topography, geology, climate and hydrology explains, in fine, the spatial distribution of $\mathrm{Li}$ isotopic ratios in the large drainage basin of the Mackenzie River. There is no simple relationship between Li isotopic composition and chemical denudation fluxes in the Mackenzie River Basin.
\end{abstract}

Keywords: lithium isotopes, river waters, silicate weathering, sediments, erosion, Mackenzie Basin Submitted on September $22^{\text {nd }} 2009$ - Revised on April $22^{\text {nd }} 2010$ 7198 words (without the references and captions) 


\section{INTRODUCTION}

Assessing the behaviour of lithium and the distribution of $\mathrm{Li}$ isotopes during weathering is of major importance for studying water/rock interactions at the surface of the Earth. This is because lithium ( ${ }^{6} \mathrm{Li} \sim 7.5 \%$ and ${ }^{7} \mathrm{Li} \sim 92.5 \%$ ) is a fluid-mobile element and, due to the large relative mass difference between its two stable isotopes, it is subject to significant low temperature mass fractionation which provides key information on the nature of weathering processes.

Recent studies have shown that the range of $\delta^{7} \mathrm{Li}$ values spans more than $40 \%$ at the Earth surface $\left(\delta^{7} \mathrm{Li}=\left({ }^{7} \mathrm{Li}{ }^{6} \mathrm{Li}_{\text {sample }} /{ }^{7} \mathrm{Li}^{6}{ }^{6} \mathrm{Li}_{\mathrm{L}-S V E C}-1\right) \times 10^{3}\right)$, (e.g. Pistiner and Henderson 2003, Rudnick et al. 2004, Kisakürek et al. 2004, Huh et al. 2004, Kisakürek et al. 2005, Hathorne and James 2006, Pogge von Strandmann et al. 2006, Vigier et al. 2009). Furthermore, the world-wide range of $\delta^{7} \mathrm{Li}$ in river waters is between +6 and $+33 \%$ (Huh et al. 1998, 2001). There are as yet few studies concerning mixed lithology basins, but these suggest that river water $\delta^{7} \mathrm{Li}$ is not affected by differences in catchment lithology (Kisakürek et al. 2005, Huh et al. 1998). Rather, lithium isotopes are thought to be strongly affected by isotope fractionation during secondary mineral formation and the degree and type of silicate weathering (Kisakürek et al. 2004, Huh et al. 2004, Kisakürek et al. 2005, Hathorne and James 2006, Pogge von Strandmann et al. 2006, Vigier et al. 2009).

To date, both the magnitude of the $\mathrm{Li}$ isotopic fractionation associated with water-rock interaction processes, and the factors controlling these fractionations, are poorly understood. However, both field and experimental studies have shown that ${ }^{6} \mathrm{Li}$ is preferentially retained by secondary minerals during silicate weathering (Pistiner and Henderson 2003, Kisakürek et al. 2004, Pogge von Strandmann et al. 2006, Vigier et al. 2009). Accordingly, the fractionation of

$\mathrm{Li}$ isotopes is dependent upon the extent of chemical weathering. Large fractionation seems to occur during superficial weathering while little fractionation is observed during more 
intense or prolonged weathering in stable environments (Huh et al. 1998, 2001, Pogge von Strandmann et al. 2006).

Lithium isotopic fractionation has been documented in numerous natural environments, with experimental and natural data (Huh et al. 2001, Pistiner and Henderson 2003, Tomascak 2004). It has been shown that partial dissolution of basalts does not result in fractionation of lithium isotopes, but that dissolution of granitic rock can cause fractionation (Pistiner and Henderson 2003). In addition, adsorption onto mineral surfaces can also be a mechanism of $\mathrm{Li}$ isotopic fractionation in the hydrosphere. Sorption of Li from aqueous solutions by mineral phases at the temperature of the Earth's surface has been highlighted by Taylor and Urey (1938), as well as by Anderson et al. (1989). Li sorption experiments utilizing several minerals (Pistiner and Henderson 2003) have revealed that Li isotopic fractionation does not occur when this element is not incorporated into the structure of the solid (physical sorption). When Li is incorporated by stronger bonds (chemical sorption), an isotopic fractionation is observed that is dependent on the chemical structure of the minerals (Anghel et al. 2002). The most significant Li isotopic fractionation factor $\left(\Delta_{\text {solution }- \text { solid }}\right) \sim+14 \%$ has been measured for gibbsite. For Li sorption processes between solution and different solids (clay minerals such as kaolinite and vermiculite, and freshwater sediments), Zhang et al. (1998) have observed even higher Li isotopic fractionation factors ( $\Delta_{\text {solution - solid }} \sim+22 \%$ ).

In the present paper, we have undertaken a systematic study of the weathering products (both dissolved load and suspended sediments) of the Mackenzie River Basin, one of the major high latitude river basins of North America. This area is of particular interest because it has previously been extensively studied and is well characterized from a lithology and weathering mass budget point of view (Vigier et al. 2001, Millot et al. 2002, Millot et al. 2003, Gaillardet et al. 2003). Also, there is a clear contrast between mountains and plains, with a fourfold increase of silicate chemical weathering rates in the plains (Millot et al. 2003). A direct comparison of silicate weathering rates and river $\mathrm{Li}$ isotope compositions can be performed. In this paper, we evaluate the potential of $\mathrm{Li}$ isotopes as a tracer of silicate weathering processes in large mixed lithology basins at the scale of a large river basin. 
This study focuses on the Mackenzie River basin and adjacent river basins (Stikine, Nass, Skeena, Fraser, and Yukon rivers). Most of the river waters and sediments are from the Mackenzie River Basin itself (Figure 1), which is located in northwestern Canada under arctic and subarctic climate. The mainstream of the Mackenzie River was sampled at two locations (samples CAN96-6 at the river mouth and CAN96-25 upstream). The main tributaries of the Mackenzie River are the Red Arctic River (CAN96-7), the Liard River (CAN96-26), the Peel River (CAN96-5), the Peace River (CAN96-15 and CAN96-37), the Slave River (CAN96-38) and the Athabasca River (CAN96-42).

The Mackenzie River basin is composed of three main structural units, corresponding to different geomorphological zones: namely, the Rocky and the Mackenzie Mountains in the western part, the Interior Platform (lowlands), and the Canadian Shield (in the eastern part), (Figure 1). Rivers belonging to a transition-zone correspond to basins draining the foothills located between the Rockies and the low-lying plains. From a mass budget point of view, the mainstream of the Mackenzie is mostly fed by tributaries draining the Interior Plain. River samples from the adjacent basins of the Yukon and Fraser Rivers are also considered here because their geological contexts are similar to those of the Upper Liard and Athabasca subbasins, both located in the Rocky Mountains. Finally, the main rivers draining the Western Canadian orogenic belt were also analysed (Nass, Skeena and Stikine River).

Sampled rivers therefore drain a large range of lithologies: volcanics and immature volcanoclastic sediments in the Western Canadian orogenic belt (Stikine terrane), carbonates and slates in the Mackenzie Mountains, marine and non-marine sedimentary rocks (Cambrian to Cretaceous limestones, shales and sandstones) in the Interior plains of the basin, and old silicate rocks (Archean granites and gneisses) in the Slave Province of the Canadian Shield. The chemical weathering conditions and physical erosion rates differ greatly depending on the runoff and basin lithology. Chemical denudation rates in this arctic zone are rather low 
compared to other major river basins, as determined by Millot et al. (2003) and Gaillardet et al. (2003). Full details concerning river samples (geological and hydrological contexts) have been published in Millot et al. (2003) for the Mackenzie River basin, in Millot et al. (2002) for the rivers of the Canadian Shield and in Gaillardet et al. (2003) for rivers of the Western Cordillera.

\section{ANALYTICAL METHODS}

\subsection{Sampling methodology, major and trace element concentration measurements}

River waters were sampled twice during the high flow stage of the summer season (August 1996 and June 1999). In the field, 10-15 L of river water was collected in acid-washed containers for major and trace elements, and isotopic measurements (Millot et al. 2003). Samples were filtered a few hours later, using a Sartorius frontal filtration unit $(0.2 \mu \mathrm{m}$ cellulose acetate filter, $142 \mathrm{~mm}$ diameter). After filtration, samples were stored in acidwashed polypropylene bottles. The river sediments were collected after drying and centrifugation of the retentate of river water filtration. The samples for cations and trace element concentrations and $\mathrm{Li}$ isotope analyses were acidified to $\mathrm{pH}=2$ with ultrapure $\mathrm{HNO}_{3}$. Bottles for anion analyses were not acidified.

Lithium concentrations (for river waters and suspended sediment samples) were determined by ICP-MS (VG PlasmaQuad II+) with indium as an internal standard, with a precision of \pm $5 \%$.

Major and trace elements are reported in Millot et al. (2003) for the Mackenzie River basin, in Millot et al. (2002) for the rivers of the Canadian Shield, and in Gaillardet et al. (2003) for rivers of the Western Cordillera respectively.

\subsection{Lithium isotope measurements}


Lithium isotopic compositions were measured using a Neptune Multi-Collector ICP-MS (Millot et al. 2004). ${ }^{7} \mathrm{Li} /{ }^{6} \mathrm{Li}$ ratios were normalized to the L-SVEC standard solution (NIST SRM 8545 , Flesch et al. 1973) following the standard-sample bracketing method. Typical in-run precision on the determination of $\delta^{7} \mathrm{Li}$ is about $0.1-0.2 \%$ ( $\left(2 \sigma_{\mathrm{m}}\right.$, standard error of the mean).

Chemical separation of Li from the matrix was achieved before isotope analyses, following a procedure modified from the technique of James and Palmer (2000) that uses a cationic exchange resin (a single column filled with $3 \mathrm{~mL}$ of BioRad $A G \AA$ ${ }^{\circledR} 50 \mathrm{~W}-\mathrm{X} 12$ resin, 200-400 mesh) and $\mathrm{HCl}$ acid media $(0.2 \mathrm{~N})$ for $30 \mathrm{ng}$ of Li. Blanks for the total chemical extraction were less than $30 \mathrm{pg}$ of $\mathrm{Li}$, which is negligible since this represents a blank/sample ratio of $<10^{-3}$

Successful quantitative measurement of Li isotopic compositions requires $100 \%$ Li recovery during laboratory processing. Therefore, frequent column calibrations were performed and repeated analysis of L-SVEC standard processed through the columns shows that no isotope fractionation occurred as a result of the purification process.

Accuracy and reproducibility of the isotopic measurements were tested by repeated analyses of three Li standard solutions (namely ${ }^{6} \mathrm{Li}-\mathrm{N}$, LiCl-N and ${ }^{7} \mathrm{Li}-\mathrm{N}$, Carignan et al. 2007). Mean values of $\delta^{7} \mathrm{Li}=-8.0 \%$ o $\pm 0.3(2 \sigma, \mathrm{n}=38), \delta^{7} \mathrm{Li}=+10.1 \%$ o $\pm 0.2(2 \sigma, \mathrm{n}=46)$ and $\delta^{7} \mathrm{Li}=+30.2 \%$ $\pm 0.3(2 \sigma, n=89)$, were obtained for ${ }^{6} \mathrm{Li}-\mathrm{N}, \mathrm{LiCl}-\mathrm{N}$ and ${ }^{7} \mathrm{Li}-\mathrm{N}$ respectively over a period of 10 months. Thus, long-term reproducibility of the Li mass analysis is better than $0.3 \%$ at the two sigma level for standard solutions ( $\sigma$ : standard deviation).

The accuracy and reproducibility of the entire method (purification procedure + mass analysis) were tested by repeated measurement of a seawater standard solution (IRMM BCR-403) after separation of Li from the matrix, for which we obtained a mean value of $\delta^{7} \mathrm{Li}=$ $+30.8 \% \pm 0.4(2 \sigma, n=15)$ over the period of the duration of the analyzes. This mean value is in a good agreement with our long-term measurements $\left(\delta^{7} \mathrm{Li}=+31.0 \% \pm 0.5,2 \sigma, \mathrm{n}=30\right.$, Millot et al. 2004) and with other values reported in the literature (see for example Carignan et al. 2004 and Tomascak 2004 for a compilation). 
For suspended sediments, as well as for sands and rocks, a total digestion of $50 \mathrm{mg}$ of crushed sample was performed over 4 days at $100^{\circ} \mathrm{C}$ in a closed beaker with a mixture of three ultrapure acids: $4 \mathrm{~mL}$ of $\mathrm{HF}(23 \mathrm{~N}), 1 \mathrm{~mL}$ of $\mathrm{HNO}_{3}(14 \mathrm{~N})$ and $0.1 \mathrm{~mL}$ of $\mathrm{HClO}_{4}(12 \mathrm{~N})$. The solution was subsequently evaporated to dryness and $4 \mathrm{~mL}$ of $\mathrm{HCl}$ acid $(6 \mathrm{~N})$ was added and left for a further 4 days at $100^{\circ} \mathrm{C}$. Sample aliquots (30 $\mathrm{ng}$ of $\mathrm{Li}$ ) of the residue of the acid dissolution were then dissolved in $0.5 \mathrm{~mL}$ of $\mathrm{HCl}(0.2 \mathrm{~N})$, before being placed on cation exchange columns for Li separation. Accuracy and reproducibility of the procedure for solid samples (dissolution + purification procedure + mass analysis) were tested by repeated measurement of the JB-2 basalt standard (Geological Survey of Japan) which gave a mean value of $\delta^{7} \mathrm{Li}=+4.9 \%$ o $\pm 0.6(2 \sigma, \mathrm{n}=17)$, in good agreement with published values (see Jeffcoate et al. 2004, Tomascak 2004 and Carignan et al. 2007 for data compilation).

\section{RESULTS}

\subsection{Dissolved phase}

Lithium concentrations (Table 1) in the Mackenzie basin river waters display a wide range of values, from $0.05 \mu \mathrm{mol} / \mathrm{L}$ (for the Skeena River in the W. Cordillera) to $1.29 \mu \mathrm{mol} / \mathrm{L}$ (for the Hay River located in the lowlands). The Mackenzie River at the river mouth (CAN96-6) has a $\mathrm{Li}$ concentration of $0.57 \mu \mathrm{mol} / \mathrm{L}$. The main tributaries, which are mainly located in the lowlying plains, show a mean value of $\mathrm{Li}$ of $0.63 \mu \mathrm{mol} / \mathrm{L},(\mathrm{n}=11)$. The group of rivers draining the Interior Platform display the highest Li contents (mean value of $0.85 \mu \mathrm{mol} / \mathrm{L}, \mathrm{n}=9$ ). In contrast, rivers of the Shield and the W. Cordillera areas display the lowest Li levels $(\sim 0.16$ $\mu \mathrm{mol} / \mathrm{L}, \mathrm{n}=4$ and $\sim 0.08 \mu \mathrm{mol} / \mathrm{L}, \mathrm{n}=3$, respectively). Also, rivers draining the Rocky Mountains have low Li contents (mean value of $0.30 \mu \mathrm{mol} / \mathrm{L}, \mathrm{n}=11$ ). Finally, Li contents for rivers located in the transition zone are intermediate between those from the Rockies and those from the low-lying plains (mean $\mathrm{Li}=0.54 \mu \mathrm{mol} / \mathrm{L}, \mathrm{n}=4$ ). 
Compared to the concentrations of dissolved Li reported in the pioneering work of Reeder et

210

211

212

213

214

215

216

217

218

219

220

221

222

223

224

225

226

227

228

229

230

al. (1972) for the Mackenzie river system (Li ranging from $<0.7$ to $4.5 \mu \mathrm{mol} / \mathrm{L}$ ), our values are clearly lower in the present case (from 0.05 to $1.29 \mu \mathrm{mol} / \mathrm{L}$ ). This difference is likely to be related to the method used for the Li determination in waters. Indeed, Reeder et al. (1972) reported a detection limit of $0.70 \mu \mathrm{mol} / \mathrm{L}(\sim 5 \mu \mathrm{g} / \mathrm{L})$ by atomic adsorption in the early 1970's, whereas it is now $\sim 0.01 \mu \mathrm{mol} / \mathrm{L}$ using modern ICP-MS techniques. Consequently, it is obvious that Reeder et al. (1972) were not able to measure low lithium concentrations in some of the rivers of the Mackenzie Basin (indeed Li was not detected in 49 samples of their suite of 101 river samples).

Lithium isotopic compositions in the Mackenzie river waters (Table 1) range from $\delta^{7} \mathrm{Li}=+9.3$ (for the Smoky River located in the transition zone) to $+29.0 \%$ (for the Yellowknife River located in the Slave Province). Rivers from the Lowland regions vary from $+10.1 \%$ to $+16.8 \%$ with an average of $+13.2 \%$. Rivers from the Rockies display higher $\delta^{7} \mathrm{Li}$ values (from $+12.2 \%$ o to $+20.5 \%$, with an average of $+15.7 \%$ ), when compared to rivers draining the plains. Rivers draining the W. Cordillera and the Canadian Shield show the heaviest isotope compositions, with $\delta^{7}$ Li ranging between +25.2 to $+29.0 \%$ for the Shield rivers and between +21.6 and $+24.9 \%$ for the western orogenic belt (Stikine terrane).

An inverse relationship of $\mathrm{Li}$ isotopic composition with $\mathrm{Li}$ concentrations is observed for the Mackenzie river system (Figure 2). It is clear from this figure that the different physiographic provinces in the basin are characterized by different domains. The large tributaries display $\delta^{7} \mathrm{Li}$ values that essentially reflect the mixture of waters from the mountains and waters from the lowlands, in the range +12.7 to $+16.5 \%$ (with an average of $+14.6 \%$ ). The Mackenzie River at river mouth (CAN96-6) shows a $\delta^{7} \mathrm{Li}$ value of $+15.0 \%$, close to both values reported by Huh et al. (1998) for the Mackenzie river mainstream ( +17.9 and $+15.7 \%$, respectively).

\subsection{River sediments and bedrocks}



range between $17.8 \mu \mathrm{g} / \mathrm{g}$ (for the Mackenzie River at river mouth) and $57.8 \mu \mathrm{g} / \mathrm{g}$ (for the Trout River in the Rockies). Lithium contents of the Mackenzie suspended sediments show almost the same range as that determined for the suspended sediments of the Orinoco basin (from 5.2 to $71.3 \mu \mathrm{g} / \mathrm{g}$, see Huh et al. 2001) and are close to the mean value of $35 \pm 11 \mu \mathrm{g} / \mathrm{g}$ reported for the Upper Continental Crust (UCC) by Teng et al. (2004).

The isotopic composition of the suspended sediments range from $-1.7 \%$ o to $+3.2 \%$, with a mean value of $+0.4 \%$ o $(n=20$, Table 2$)$, identical, within uncertainties, to the estimate of the UCC ( $\delta^{7} \mathrm{Li}$ from -2 to $+2 \%$, Teng et al. 2004). Suspended sediments from the main tributaries of the Mackenzie Basin display slightly negative $\delta^{7} \mathrm{Li}$ values (from -1.6 to $-0.2 \%$ ) whereas $\delta^{7} \mathrm{Li}$ of suspended sediments of rivers located in the Rocky Mountains are slightly positive (from +0.3 to $+3.2 \%$ ). The suspended sediments of the Nass and Stikine Rivers (W. Cordillera) exhibit positive and similar isotope signatures $\left(\delta^{7} \mathrm{Li}=+1.0\right.$ and $+1.2 \%$ respectively). As for Li content, the range of $\delta^{7} \mathrm{Li}$ for suspended sediments of the Mackenzie Basin is comparable with the values obtained by Huh et al. (2001) for silicate regions of the Orinoco Basin. $\delta^{7} \mathrm{Li}$ values measured in suspended sediments are also in good agreement with the range reported by Kisakürek et al. (2005) for the Himalayan rivers $(-3.9$ to $+3.0 \%)$. The sand sample collected at the mouth of the Mackenzie River (CAN96-6) has a Li concentration of $47.4 \mu \mathrm{g} / \mathrm{g}$, which is lower than the $\mathrm{Li}$ content of the corresponding suspended material $(57.8 \mu \mathrm{g} / \mathrm{g})$ and a $\mathrm{Li}$ isotopic composition of $-0.5 \%$, not significantly different from that of the corresponding suspended sediments $(-0.9 \%)$. Bedrocks (carbonates and black shales) sampled in the basin, and assumed to be representative of the main type of rocks exposures, display Li contents ranging between 1.5 and $64.4 \mu \mathrm{g} / \mathrm{g}$ (Table 3). The carbonate samples from the Rocky Mountains (CAN99-65) display the lowest concentration $(1.5 \mu \mathrm{g} / \mathrm{g})$, in agreement with literature data reported for other carbonates (e.g. Huh et al. 2001, Hathorne and James 2006). In contrast, Li contents in blackshales from the Interior Platform are high (29.1 and $64.4 \mu \mathrm{g} / \mathrm{g})$. Two glacial tills sampled 
within the Slave Province (Yellowknife and Prosperous Lake) display different Li concentrations of 16.2 and $54.6 \mu \mathrm{g} / \mathrm{g}$ respectively.

The carbonate sample (CAN99-65, Rocky Mountains) has the highest $\delta^{7}$ Li value $(+7.2 \%$ ), in agreement with other values reported for continental carbonates by Huh et al. (2001). This value is likely to reflect a mixing between pure marine carbonate $\left(\delta^{7} \mathrm{Li}>+25 \%\right.$, Tomascak 2004, Hall et al. 2005, Hathorne and James 2006, Vigier et al. 2007) and detrital phases with much lower $\delta^{7} \mathrm{Li}$ values and higher Li contents. $\delta^{7} \mathrm{Li}$ for the blackshales are negative $(-1.0$ and $-1.1 \%$ for the Interior plains and for the Transition zone samples respectively), but remain close to the estimate of the UCC. Finally, the two glacial till samples display relatively similar $\delta^{7}$ Li values of +4.8 and $+5.2 \%$ respectively.

\section{DISCUSSION}

\subsection{Sources of dissolved lithium}

The sources of dissolved lithium in the river waters of the Mackenzie Basin can be assumed to be either released by rock weathering (including solubilisation of the bedrock, and destabilisation or desorption from secondary minerals), derived from the atmosphere (via precipitation or wet deposition), or derived from groundwater input. First of all, atmospheric input can be evaluated using chloride concentrations if no evaporite is present within the drainage basin. This is the case for most of the rivers of the Mackenzie Basin, as shown by Millot et al. (2002), Millot et al. (2003) and Gaillardet et al. (2003). In particular, rivers draining the Shield area, characterized by low chemical weathering rates, are good candidates for estimating the atmospheric input of Li. Rivers draining the Canadian Shield have low dissolved Li contents (from 0.07 to $0.2 \mu \mathrm{mol} / \mathrm{L}$ ) and display the highest $\delta^{7} \mathrm{Li}$ values, close to that of the ocean $\left(\delta^{7} \mathrm{Li}=+31.0 \%\right.$ ), a priori suggesting a marine origin for $\mathrm{Li}$ via seasalt input through precipitation. Then, if we assume that all chloride in the Shield rivers (with $\mathrm{Li} / \mathrm{Cl}=$ 
$5 \times 10^{-3}$ and $\delta^{7} \mathrm{Li}=+25.2 \%$ on average) is of atmospheric origin and that marine salts have seawater $\mathrm{Li} / \mathrm{Cl}$ molar ratios of $5 \times 10^{-5}$ and $\delta^{7} \mathrm{Li}=+31.0 \%$, it can be calculated that only a small fraction of riverine $\mathrm{Li}(<1 \%)$ in these rivers originates from seasalt input through precipitation. The same calculation for rivers draining the Western Cordillera (i.e. the rainy region: 1500$1750 \mathrm{~mm} /$ year compared to $350 \mathrm{~mm} / \mathrm{yr}$ in the Shield area) indicates that a maximum of only $\sim 0.4 \%$ riverine Li could have been supplied by precipitation.

We provided evidence in a previous paper (Millot et al. 2002), that the rivers of the Shield area (Slave Province) are characterized by a chloride excess compared to a pure marine input, and we attributed their relatively high $\mathrm{Cl}$ concentrations to the dissolution of evaporitetype aerosols derived from the dry area located south of the Great Slave Lake. Cambrian evaporites occur at the base of the sedimentary basin of the lowlands, and these have contributed to redeposited salt in modern lakes. The Salt River is one of the rivers that is highly influenced by the dissolution of these formations. Although this river was not analysed in the present work, $\mathrm{Li}$ and $\mathrm{Na}$ concentrations of the Salt River $(\mathrm{Li}=4.5 \mu \mathrm{mol} / \mathrm{L}$ and $\mathrm{Na}=$ $276.45 \mathrm{mmol} / \mathrm{L}$ ) have been reported by Reeder et al. (1972). The typical Li/Na ratio of this river is $1.6 \times 10^{-5} \mathrm{~mol} / \mathrm{mol}$. Considering this ratio along with the highest $\mathrm{Cl}$ concentration found in rivers draining the Slave Province $(80 \mu \mathrm{mol} / \mathrm{L})$, we estimate there is a negligible Li input from evaporites in the Shield rivers (less than $0.4 \%$ of lithium derived from evaporite).

In summary, our calculations indicate that the contribution of Li coming from precipitation and wet deposition is negligible, and that dissolved $\mathrm{Li}$ in all sampled rivers is mainly derived from weathering of silicate and carbonate rocks. Although carbonates have relatively low Li concentrations ( $<1 \mu \mathrm{g} / \mathrm{g}$ ) compared to silicates (higher than $50 \mu \mathrm{g} / \mathrm{g}$ ), their higher dissolution rates may make them a significant source of Li in carbonate rich-regions. Millot et al. (2002) showed that the areas of the Mackenzie Basin which are most influenced by carbonate dissolution are the Rocky and Mackenzie Mountains. In contrast, the lowlands are less influenced by this lithology and the Shield area displays no input from carbonate weathering. The proportions of lithium derived from silicate and carbonate weathering can be calculated from the results of the inversion model (Millot et al. 2003) which allowed us to determine, for 
each major element present in the dissolved phase, the proportion derived from the weathering of silicate and carbonate end-members within the Mackenzie River Basin. We use a mean Li/Ca molar ratio of $15 \times 10^{-6}$ for carbonates, in agreement with Li/Ca molar ratios ranging from $10 \times 10^{-6}$ to about $20 \times 10^{-6}$ reported in carbonates elsewhere (Hall and Chan 2004, Lear and Rosenthal 2006, Hathorne et al. 2009), and determine that the carbonate end-member contribution is very low for lithium. Between $90.5 \%$ and $99.4 \%$ of dissolved lithium is thus derived from silicate weathering in the Mackenzie River Basin (Figure 3).

These estimates agree well with previous studies that have inferred that most riverine $\mathrm{Li}$ derives from silicate lithologies (Huh et al. 1998, Kisakürek et al. 2005). In addition, the absence of a correlation between $\mathrm{Li}$ and $\mathrm{Sr}$ isotopic ratios (from Millot et al. 2003) argues against a carbonate weathering control on riverine $\mathrm{Li}$ isotopic composition. We therefore conclude that Li concentrations in the dissolved load of rivers in the Mackenzie Basin are essentially controlled by silicate weathering. Dissolved Li isotopic compositions are however highly variable within the Mackenzie river basin (from +9.3 to $+29.0 \%$ ), suggesting variable fractionation of $\mathrm{Li}$ isotopes during silicate weathering.

\section{2. $\mathrm{Li}$ isotopes and silicate weathering regimes}

\subsubsection{Evidence for isotope fractionation during chemical weathering}

River dissolved loads are systematically enriched in ${ }^{7} \mathrm{Li}$ relative to bedrocks and suspended particles (Figure 4). In this regard, lithium is similar to boron (Lemarchand and Gaillardet 2006). However, the dissolved loads exhibit a large range of $\delta^{7} \mathrm{Li}$ values across the sampled rivers. A part of this variability may derive from the $\delta^{7} \mathrm{Li}$ of bedrocks, which might differ between the main provinces of the Mackenzie Basin. Literature data indicate that the Li isotopic composition of continental granites (-2 to $+3 \%$, Teng et al. $2004,2006,2008,2009$ ) is slightly different from the shales and loesses from which they were derived ( -3 to $+5 \%$ ). The $\mathrm{Li}$ isotopic composition of the Canadian Shield bedrock (mainly consisting of granites 
and associated crystalline rocks, Millot et al. 2002) is averaged in the glacial till samples reported in Table 3. In concordance with literature data, the $\delta^{7} \mathrm{Li}$ values measured in till samples are higher than those measured in the bedrocks from the lowlands and the Rocky Mountains (which are mainly recycled materials such as shales, blackshales, slates and a few low grade metamorphic rocks). In Figure 4, we report $\delta^{7}$ Li values in silicate bedrocks compiled from the literature together with the results from this study. Suspended sediment and sand samples from the Mackenzie rivers fall within the range of bedrocks defined by our bedrock samples and by literature data (Figure 4). However, a positive trend between $\delta^{7} \mathrm{Li}$ and $\mathrm{Na} / \mathrm{Al}$ is observed (Figure 5). Due to the high solubility of $\mathrm{Na}$ during chemical weathering compared to Al which is immobile, the Na/Al ratio can be regarded as "a weathering index". The low $\mathrm{Na} / \mathrm{Al}$ ratios associated with low $\delta^{7} \mathrm{Li}$ values suggests that lithium isotopes are fractionated by chemical weathering processes. The direction of the fractionation in the suspended sediments is consistent with the enrichment of ${ }^{7} \mathrm{Li}$ in the dissolved load since the lowest $\mathrm{Na} / \mathrm{Al}$ are associated with the lowest $\delta^{7} \mathrm{Li}$. Since the suspended sediments of the Mackenzie rivers are essentially derived from sedimentary rocks (the Shield area does not contribute significant sediment), it is difficult to conclude whether the Na loss recorded in the $\mathrm{Na} / \mathrm{Al}$ ratio is due to present day weathering conditions, or whether the low $\mathrm{Na} / \mathrm{Al}$ ratios are inherited from previous cycles of erosion and sedimentation. Examples of shale composites reported in the literature, such as the PAAS or NASC (Post Archean Australian Shale and North American Shale Composite: Holland 1978, Taylor and MacLennan 1985) do indeed show $\mathrm{Na}$ depletion compared to granodioritic Upper Continental Crust (Taylor and MacLennan 1985, Gaillardet et al. 1999). Given the low grade silicate weathering in the Mackenzie River Basin (Millot et al. 2003), and the overlap of bedrock and suspended sediment $\mathrm{Li}$ isotopes compositions (Figure 4), we favour the hypothesis that $\mathrm{Na} / \mathrm{Al}$ in the suspended sediments essentially records bedrock geochemistry rather than present day weathering products. Therefore the trend of increasing $\mathrm{Li}$ isotopic composition with $\mathrm{Na} / \mathrm{Al}$ ratio (Figure 5) is likely inherited from the bedrock history. From a mass budget perspective, 
373 it is not easy to estimate the partitioning of Li transported in the dissolved and particulate

374 load because chemical weathering does not proceed at steady state (Vigier et al. 2001). 375 However, the above considerations suggest that the dissolved load clearly reflects the 376 fractionation of $\mathrm{Li}$ isotopes during chemical weathering (with the enrichment of ${ }^{7} \mathrm{Li}$ in the

\subsubsection{Influence of the weathering regime}

We show in the following that the range of $\mathrm{Li}$ isotopic composition measured in the rivers of the Mackenzie Basin is related to the weathering regime.

The $\mathrm{Li} / \mathrm{Na}^{*}$ ratio in the dissolved load, when compared to that in the bedrock can be used as an index of Li mobility compared to $\mathrm{Na}$. Both elements are alkali metals, thus mobile during water-rock interactions. As shown by a number of previous studies, in contrast to $\mathrm{Na}$, $\mathrm{Li}$ is likely to be incorporated into secondary minerals, such as clays. By analogy with the study of Georg et al. (2007) concerning the mobility of Si isotopes during chemical weathering in Iceland, we can define $\mathrm{f}_{\mathrm{Li}}$, the fraction of $\mathrm{Li}$ remaining in solution relative to $\mathrm{Na}$, as:

$$
f_{L i}=\frac{(L i / N a *)_{\text {dissolved }}}{(L i / N a)_{\text {bedrock }}}
$$

where $\mathrm{Na}^{*}$ is the $\mathrm{Na}$ concentration corrected for atmospheric input and for evaporite dissolution using the results of Millot et al. (2003). Correction for evaporite dissolution only significantly affects a few samples. A value of 1 for $f_{L i}$ means that chemical weathering is 
congruent. While dissolution is usually thought to be incongruent, precipitation of secondary phases is the most probable process that will fractionate $\mathrm{Li}$ and $\mathrm{Na}$, $\mathrm{Li}$ being known to have affinity for clay minerals, while $\mathrm{Na}$ is much more mobile and hardly reincorporated into clay minerals.

We used the suspended sediment compositions, where available, to estimate the bedrock $\mathrm{Li} / \mathrm{Na}$ ratio. In the Canadian Shield province, because rivers at the time of sampling contained very low levels of suspended sediment, we used two glacial till samples (Table 3) which display contrasting $\mathrm{Li} / \mathrm{Na}$ ratios. The calculated $\mathrm{f}_{\mathrm{Li}}$ in the rivers of the Mackenzie basin range between 0.1 (in the lowlands and main tributaries) to 0.8 in the rivers of the Shield area. Intermediate values are found in the Rocky Mountains and in the Western Cordillera. This indicates that the reincorporation of $\mathrm{Li}$ into secondary phases is more important in the lowlands and main tributaries than in the Cordillera and Rocky Mountain samples. In Figure 6, the dissolved Li/Na in the Shield rivers were normalized to the Prosperous Lake till sample. If the till sample CAN96-31 (Yellowknife) is used as a reference for the parent bedrock in the Slave Province, then $f_{L i}$ values higher than 1 are found. Values of $f_{L i}$ higher than 1 would mean a preferential leaching of Li compared to Na. Although Prosperous Lake till sample is our preferred bedrock estimate here, we nevertheless consider $f_{L i}$ higher than 1 (and CAN96-31 as a source rock) as a possible scenario. Despite these uncertainties on the bedrock in the Shield province, $f_{L i}$ provides a relative indication of $\mathrm{Li}$ mobility during weathering.

When the isotopic composition of dissolved lithium is plotted as a function of $\mathrm{f}_{\mathrm{Li}}$, a correlation appears (Figure 6). This correlation can be explained by a binary mixing between waters draining areas characterized by two markedly different weathering regimes.

The first end-member needed to account for the correlation between $\mathrm{f}_{\mathrm{Li}}$ and $\delta^{7} \mathrm{Li}$ of the dissolved load corresponds to a weathering regime where Li is significantly precipitated in the solids compared to $\mathrm{Na}$, most probably incorporated into Li-rich secondary minerals (clays). The lowlands and the transition zone areas best characterize this weathering regime since they display the lowest $f_{L i}$ values. Numerous studies have shown that $\mathrm{Li}$ isotopes are 
fractionated during the formation of secondary minerals. The $\sim 13 \%$ isotopic shift between the composition of the dissolved load and the bedrock in the lowlands is, to a first order, compatible with the estimated clay-solution isotopic fractionation at equilibrium (Taylor and Urey 1938, Chan et al. 1992, Zhang et al. 1998, Pistiner and Henderson 2003, Vigier et al. 2008). The formation of secondary solids, being kinetically limited, requires a favorable environment. Using boron isotopes, Lemarchand and Gaillardet (2006) have suggested that most of the dissolved boron in rivers is derived from the shallow groundwater system (drift aquifers). As shown by Lemay (2002), high lithium concentrations (3-15 $\mu \mathrm{mol} / \mathrm{L})$ are also measured in these groundwaters. The correlation between boron and lithium concentrations that links both rivers and groundwaters (Figure 7) strongly argues for a significant input of Li to the lowland rivers from groundwaters. Because groundwaters have long residence times relative to surface waters, chemical weathering reactions can proceed further than in the Shield or Rocky Mountains areas where the residence time of water is not sufficiently long (Lemarchand and Gaillardet 2006). We therefore suggest that the residence time of water in groundwater counteracts the effect of low temperature and favors the formation of secondary minerals that fractionate Li isotopes (Figure 6) at equilibrium.

The second endmember in Figure 6 corresponds to the Shield and Rocky Mountains areas, and displays the highest $\delta^{7} \mathrm{Li}$ and $\mathrm{f}_{\mathrm{Li}}$ values. This situation may appear as a paradox because $\mathrm{f}_{\mathrm{Li}}$ indicates no or low $\mathrm{Li}$ incorporation in secondary products of weathering, while the isotopic shift between $\mathrm{Li}$ in the bedrock and dissolved $\mathrm{Li}$ is at its maximum (from +16 to $+22 \%$ ). The Rocky Mountains and the Shield province are areas characterized by particularly low chemical weathering rates (Millot et al. 2003), in contrast to the lowlands. These regions have been deglaciated relatively recently and are characterized by abundant bare rocks and poorly developed soils. The Rocky and Mackenzie Mountains areas have relatively high river sediment yields with sediments mostly derived from glacial erosion (Millot et al. 2003) and not from soils. The Shield area is characterized by important glacial till deposits. Several hypotheses can be invoked to explain the enrichment of ${ }^{7} \mathrm{Li}$ in the waters of the Rocky Mountains and of the Shield area. The most evident possibility is that the formation of some 
secondary mineral fractionating $\mathrm{Li}$ isotopes. As indicated by the $\mathrm{f}_{\mathrm{Li}}$ values close to 1 , the incorporation of Li into secondary phases should not be quantitatively important in these regions but should however be visible in terms of isotope fractionation. A good candidate is $\mathrm{Mn}$ and Fe-oxyhydroxide minerals. Adsorption of Li onto Fe and Mn oxyhydroxide surfaces have been reported by Chan and Hein (2007) with preferential enrichment of ${ }^{6} \mathrm{Li}$ in the deposit, thus consistent with the observed heavy isotope enrichment in the fluids. A recent study reports the enrichment of the heavy isotope of $\mathrm{Li}$ in the dissolved load of glacial and non-glacial rivers from Greenland and attributes it to the preferential uptake of ${ }^{6} \mathrm{Li}$ during inner sphere sorption of $\mathrm{Li}^{+}$on the Fe-oxyhydroxide surfaces (Wimpenny et al. 2010). The same mechanism can be invoked here. The difference between the study of Wimpenny et al. (2010) and our study is that the Shield rivers, that have ${ }^{7}$ Li-enriched waters, are not sulfaterich and therefore that sulfide oxidation, a mechanism proposed by the authors to explain the abundance of Fe-oxides in Greenland, is not applicable to the Shield rivers. The presence of Fe-oxyhydroxides minerals in the Shield rivers could be tested by analysing Mn and Fe river deposits often found in river bedloads, at the surface of blocks and boulders for example. In addition, saturation state calculations (using PHREEQC modelling) indicate that the waters are supersaturated with respect to goethite in this area.

A second possibility to explain the enrichment of ${ }^{7} \mathrm{Li}$ in the dissolved load of the Shield and Mackenzie Mountain rivers could be a fractionation of Li isotopes during mineral dissolution. Experimental work on basalt dissolution does not show evidence of $\mathrm{Li}$ isotope fractionation during dissolution (Pistiner and Henderson 2003), but we can imagine a number of natural processes potentially able to fractionate $\mathrm{Li}$ isotopes during mineral dissolution. The preferential release of ${ }^{7} \mathrm{Li}$ could be possible either by the preferential dissolution of ${ }^{7} \mathrm{Li}$ enriched phases, or as a transient effect of the leaching process with formation of unstable secondary phases such as Si-gel layers around minerals. So far, Li isotope heterogeneity at the mineral scale has not been observed within a single bedrock, but we cannot exclude the existence of low temperature minerals that would show ${ }^{7} \mathrm{Li}$ enrichments. What is interesting here, is that the ${ }^{7} \mathrm{Li}$ enrichment in waters is observed in the geological context of glacial 
erosion (still active in the Rockies and in the form of glacial deposits in the Shield area). The abundance of fine glacial flour allows specific weathering reactions to occur, that have been observed experimentally (in columns of grind granitic material, White et al. 1998) or in nature (Anderson et al. 1989). In particular fast dissolving accessory phases like carbonates and sulfides have been shown to contribute significantly to solute export in the early stages of weathering.

Whatever the reason for $\mathrm{Li}$ isotope fractionation, our data do show that incipient weathering of rocks can produce ${ }^{7} \mathrm{Li}$ enriched fluids. The similar enrichments found in Greenland (Wimpenny et al. 2010) or in very recently deglaciated moraine in the granitic Swiss Alps (Lemarchand et al. 2009) shows that $\mathrm{Li}$ isotopes are very sensitive to the early stages of chemical weathering. Future studies will be necessary to investigate Li isotope fractionation in incipient weathering conditions and the isotopic heterogeneity of bedrocks to precisely determine the mechanisms that result in the preferential release of heavy $\mathrm{Li}$ isotopes in solution.

According to the above discussion, all sampled rivers in the Mackenzie Basin have an isotopic composition reflecting a mixture of water masses that have interacted with bedrock minerals according to two contrasting weathering regimes. On one hand, oxyhydroxide formation and/or leaching of comminuted bedrock produces ${ }^{7}$ Li-enriched waters, similarly to that occurring in glacial and non glacial rivers from Greenland. On the other hand, the more optimum weathering conditions of the low-lying plain aquifers will produce waters with $\mathrm{Li}$ isotopic compositions lower by about $20 \%$. As indicated by the previous studies of our group, the weathering rates of silicates in these two contrasted environments differ by a factor of 34, probably accelerated in the lowlands by the contribution of groundwaters (Lemarchand and Gaillardet 2006) and the chelating effects of organic matter (Millot et al. 2003). The Li isotopic data presented here show that the Li isotopic signature of waters is more influenced by the precipitation of specific secondary phases than weathering rates. The relationship between chemical weathering rates of silicates (calculated from the inversion of major element concentrations and $\mathrm{Sr}$ isotopic ratios by Millot et al. 2003), and $\delta^{7} \mathrm{Li}$ measured in the 
dissolved loads is shown on Figure $8 \mathrm{a}$. There is no clear relationship at the scale of the Mackenzie River Basin between the Li isotopic composition and the specific flux of chemical denudation, showing that secondary mineral formation is not necessarily related to denudation fluxes. In particular, the high fluxes observed for the Western Cordillera and visible in Figure 8 are due to the combined effects of runoff and the volcanic nature of bedrocks (Gaillardet et al. 2003). The absence of a relationship between chemical denudation rate and water lithium isotopic composition is in contrast with the relationship observed on small monolithologic rivers in Iceland (Vigier et al. 2009).

Two trends of $\delta^{7} \mathrm{Li}$ with total dissolved load derived from silicate weathering in $\mathrm{mg} / \mathrm{L}$ are observed (Figure 8b), corresponding to the two weathering regimes described above. The first trend of increasing ${ }^{7} \mathrm{Li}$-enrichment with dissolved solutes only contains samples from the Shield and Rocky-Mackenzie Mountains from the first weathering regime described above. By contrast, the waters most influenced by the second weathering regime show constant Li isotopic composition with total dissolved load concentration derived from silicate weathering. Figure $8 \mathrm{~b}$ confirms the broad idea that $\mathrm{Li}$ isotopes are indicative of the regime weathering. Regimes characterized by secondary clay formation have Li isotopic composition between 10 and $15 \%$ and show no relationship with silicate weathering rates, while weathering regimes characterized by incipient weathering, or weathering of comminuted bedrocks, are characterized by higher Li isotopic composition.

\section{CONCLUSIONS}

The $\mathrm{Li}$ isotopic composition measured in the rivers of the Mackenzie Basin shows that ${ }^{7} \mathrm{Li}$ is enriched in the dissolved load and that $\delta^{7} \mathrm{Li}$ can vary by $20 \%$ within a large river basin. The $\delta^{7} \mathrm{Li}$ of the particulate load reflects that of the bedrock and ranges between -2 and $+3 \%$. Our study shows that dissolved $\mathrm{Li}$ in river waters is essentially derived from the weathering of silicates and that $\mathrm{Li}$ isotopic ratios of the dissolved load depends on the weathering regime of silicates. 
540 If $\mathrm{Na}$ is considered as a soluble element not incorporated in secondary phases, river waters

541 showing $\mathrm{Li} / \mathrm{Na}$ ratios much lower than the bedrock ratio have the lowest isotopic 542 compositions. Although the fractionation coefficients between solution and newly formed 543 solids remain poorly known and need to be better constrained by experimental work, our 544 isotopic data are consistent with the incorporation of $\mathrm{Li}$ into clay minerals at equilibrium. 545 Groundwaters, in particular shallow aquifers in the low-lying plains of the basin, seem to play 546 an important role in the acquisition of the dissolved $\mathrm{Li}$ isotope composition, probably because 547 high residence times favor the formation of clay mineral. The most ${ }^{7}$ Li-enriched waters are 548 observed in the Rocky Mountains and in the Shield areas of the basin. In these areas, by 549 analogy to previous work in Greenland (Wimpenny et al. 2010), we suggest that high $\delta^{7} \mathrm{Li}$ 550 values in rivers result from the fractionation associated with $\mathrm{Li}$ sorption onto $\mathrm{Mn}$ and Feoxyhydroxide surfaces. However, another mechanism could be that leaching is likely to be a non negligible process of water-rock interaction due to surficial or incipient weathering, being able to produce ${ }^{7}$ Li-enriched waters. Experimental work will be necessary for better understanding the behaviour of $\mathrm{Li}$ isotopes in incipient weathering regimes. To summarize, this large scale study shows that dissolved $\mathrm{Li}$ is essentially derived from silicate weathering but shows that silicate weathering does not have a unique isotopic signature. A very large variability of $\mathrm{Li}$ isotopic ratios exists within the Mackenzie Basin and is strongly spatialized. This is an important result if Li isotopes in the ocean are to be used as a proxy for the secular evolution of the Earth's surface. This study suggests that, rather than weathering fluxes, the weathering regime controls the $\mathrm{Li}$ isotopic signature of silicate weathering. Future work will have to address the role of the different parameters that define the weathering regime: time, climate, hydrological setting, residence time of water, biological parameters. 


\section{Acknowledgements:}

566

567 This work was supported by the French program funded by the INSU-CNRS (PNSE 568 contribution 322). We would like to express special thanks to B. Dupré for measurements of 569 trace elements in Toulouse University. We also would like to acknowledge B. Dupré, C. 570 Gariépy and D. Lemarchand for their help in collecting river samples. We thank E. 571 Lemarchand and E.T. Tipper for fruitful discussions. RM would like to thank Ph. Négrel and 572 T.D. Bullen for comments in an earlier version of the manuscript and the Research Division 573 of BRGM is also acknowledged for funding. We thank R. James, P. Pogge van Strandmann 574 and B. Reynolds for providing critical comments that improved this manuscript. D. Vance is 575 also thanked for editorial handling and constructive comments. Finally, we also would like to 576 thank P. Burnard and R.H. Hilton for comments and English corrections. This is IPGP 577 contribution $n^{\circ} 2581$ and BRGM contribution $n^{\circ} 6327$.

578

579 
581

582

583

584

585

586

587

588

589

590

591

592

593

594

595

596

597

598

599

600

601

602

603

604

605

606

607

\section{References}

Anderson M.A., Bertsch P.M., and Miller W.P. (1989) Exchange and apparent fixation of Lithium in selected soils and clay minerals. Soil Sci., 148, 46-52.

Anghel I., Turin H.J., and Reimus P.W. (2002) Lithium sorption to Yucca mountain tuffs. Appl. Geochem., 17, 819-824.

Calmels D., Gaillardet J. Brenot A., France-Lanord C. (2007) Sustained sulfide oxidation by physical erosion processes in the Mackenzie River basin: Climatic perspectives. Geology, 35: 1003-1006.

Carignan J., Cardinal D., Eisenhauer A., Galy A., Rehkämper M., Wombacher F., Vigier N. (2004) A reflection on $\mathrm{Mg}, \mathrm{Ca}, \mathrm{Cd}, \mathrm{Li}$ and $\mathrm{Si}$ isotopic measurements and related reference materials. Geostandards and Geoanalytical Research, 28: 139-148.

Carignan J., Vigier N., Millot R. (2007) Three secondary reference materials for Li isotopic measurements: ${ }^{7} \mathrm{Li}-\mathrm{N},{ }^{6} \mathrm{Li}-\mathrm{N}$ and LiCl-N. Geostandards and Geoanalytical Research, 31: 712.

Chan L.H., Edmond J.M. Thompson G., Gillis K. (1992) Lithium isotopic composition of submarine basalts: implications for the lithium cycle to the ocean, Earth Planet. Sci. Lett., 108: $151-160$.

Chan L.H., Hein J.R. (2007) Lithium contents and isotopic compositions of ferromanganese deposits from the global ocean. Deep-sea research part II - topical studies in Oceanography, 54: 1147-1162.

Flesch G.D., Anderson A.R., Svec H.J. (1973) A secondary isotopic standard for ${ }^{6} \mathrm{Li} /{ }^{7} \mathrm{Li}$ determinations. International Journal of Mass Spectrometry and Ion Physics, 12: 265-272.

Gaillardet J., Dupré B., Louvat P., Allègre C.J. (1999) Global silicate weathering and $\mathrm{CO}_{2}$ consumption rates deduced from the chemistry of large rivers. Chemical Geology, 159: 330.

Gaillardet J., Millot R., Dupré B. (2003) Chemical denudation rates of the western Canadian orogenic belt: the Stikine terrane. Chemical Geology, 201: 257-279. 
Georg R.B., Reynolds B.C., West A.J., Burton K.W., Halliday A.N. (2007) Silicon isotope variations accompanying basalt weathering in Iceland. Earth and Planetary Science Letters, 261: 476-490.

Hall J.M., Chan L.H. (2004) Li/Ca in multiple species of benthic and planktonic foraminifera: thermocline, latitudinal, and glacial-interglacial variation. Geochimica et Cosmochimica Acta, 68: 529-545.

Hall J.M. , Chan L.H., McDonough W.F., Turekian K.K. (2005) Determination of the lithium isotopic composition of planktic foraminifera and its application as a paleo-seawater proxy. Marine Geology, 217: 255-265.

Hathorne E.C., James R.H. (2006) Temporal record of lithium in seawater: A tracer for silicate weathering? Earth and Planetary Science Letters, 246: 393-406.

Hathorne E.C., James R.H. Lampitt R.S. (2009) Environmental versus biomineralization controls on the intratest variation in the trace element composition of the planktonic foraminifera G. inflata and G. scitula. Paleoceanography, 24: PA4204.

Holland H.D. (1978) The chemistry of oceans and atmosphere, Wiley and Sons, New York.

Huh Y., Chan L.C., Zhang L., Edmond J.M. (1998) Lithium and its isotopes in major world rivers: implications for weathering and the oceanic budget. Geochimica et Cosmochimica Acta, 62: 2039-2051.

Huh Y., Chan L.C., Edmond J.M. (2001) Lithium isotopes as a probe of weathering processes: Orinoco River. Earth and Planetary Science Letters, 194: 189-199.

Huh Y., Chan L.C., Chadwick O.A. (2004) Behavior of lithium and its isotopes during weathering of Hawaiian basalt. Geochemistry, Geophysics, Geosystems, 5: 1-22.

James R.H., Palmer M.R. (2000) The lithium isotope composition of international rock standards. Chemical Geology, 166: 319-326.

Jeffcoate A.B., Elliott T., Thomas A., Bouman C. (2004) Precise, small sample size determinations of lithium isotopic compositions of Geological Reference Materials and modern seawater by MC-ICP-MS. Geostandards and Geoanalytical Research, 28: 161172. 
Kisakürek B., Widdowson M., James R.H. (2004) Behaviour of Li isotopes during continental weathering: the Bidar laterite profile, India. Chemical Geology, 212: 27-44.

Kisakürek B., James R.H., Harris N.B.W. (2005) Li and $\delta^{7} \mathrm{Li}$ in Himalayan rivers: Proxies for silicate weathering? Earth and Planetary Science Letters, 237: 387-401.

Lear C.H., Rosenthal Y. (2006) Benthic foraminiferal Li/Ca: insights into Cenozoic seawater carbonate saturation state. Geology, 34: 985-988.

Lemarchand D., Gaillardet J. (2006) Transient features of the erosion of shales in the Mackenzie basin (Canada), evidences from boron isotopes. Earth and Planetary Science Letters, 245: 174-18.

Lemarchand E., Tipper E.T., Hindshaw R., Wiederhold J.G., Reynolds B.C., Bourdon B., Kretzchmar R. (2009) Li isotope fractionation in surface waters of an alpine granitic catchment. Goldschmidt Conference Abstract A742.

Lemay T.G. (2002) Geochemical and isotope data for formation water from selected wells, cretaceous to quaternary succession, Athabasca oil sand (in situ) area, Alberta, EUB/AGS Geo-Note 2002-02: 1-30.

Millot R., Gaillardet J., Dupré B., Allègre C.J. (2002) The global control of silicate weathering rates and the coupling with physical erosion: new insights from the Canadian Shield. Earth and Planetary Science Letters, 196: 83-98.

Millot R., Gaillardet J., Dupré B., Allègre C.J. (2003) Northern latitude chemical weathering rates: clues from the Mackenzie River Basin, Canada. Geochimica et Cosmochimica Acta, 67: 1305-1329.

Millot R., Guerrot C., Vigier N. (2004) Accurate and high-precision measurement of lithium isotopes in two reference materials by MC-ICP-MS. Geostandards and Geoanalytical Research, 28: 153-159.

Négrel Ph., Allègre C.J., Dupré B., Lewin E. (1993) Erosion sources determined by inversion of major and trace element ratios and strontium isotopic ratios in river water: the Congo Basin case. Earth and Planetary Science Letters, 120: 59-76. 
Pistiner J.S., Henderson G.M. (2003) Lithium isotope fractionation during continental weathering processes. Earth and Planetary Science Letters, 214: 327-339.

Pogge von Strandmann P.A.E., Burton K.W., James R.H., van Calsteren P., Gislason S.R., Mokadem F. (2006) Riverine behaviour of uranium and lithium isotopes in an actively glaciated basaltic terrain. Earth and Planetary Science Letters, 251: 134-147.

Reeder S.W., Hitchon B., Levinson A.A. (1972) Hydrogeochemistry of the surface waters of the Mackenzie River drainage basin, Canada-I. Factors controlling inorganic composition. Geochimica et Cosmochimica Acta, 36: 825-865.

Rudnick R.L., Tomascak P.B., Njo H.B., Robert Gardner L. (2004) Extreme lithium isotopic fractionation during continental weathering revealed in saprolites from South Carolina. Chemical Geology, 212: 45-57.

Taylor S.R., Urey H.C. (1938) Fractionation of the lithium and potassium isotopes by chemical exchange with zeolites, J. Chem. Phys. 6: 429-438.

Taylor S.R., MacLennan S.M. (1985) The continental crust: its composition and evolution, Blackwell Scientific Publications, 312 p.

Teng F.Z., McDonough W.F., Rudnick R.L., Dalpé C., Tomascak P.B., Chappell B.W., Gao S. (2004) Lithium isotopic composition and concentration of the upper continental crust. Geochimica et Cosmochimica Acta, 68: 4167-4178.

Teng F.Z., McDonough W.F., Rudnick R.L., Walker R.J. (2006) Diffusion-driven extreme lithium isotopic fractionation in country rocks of the Tin Mountain pegmatite. Earth and Planetary Science Letters, 243: 701-710.

Teng F.Z., Rudnick R.L., McDonough W.F., Gao S., Tomascak P.B., Liu Y. (2008) Lithium isotopic composition and concentration of the deep continental crust. Chemical Geology, 255: 47-59.

Teng F.Z., Rudnick R.L., McDonough W.F., Wu F.Y. (2009) Lithium isotopic systematics of A-type granites and their mafic enclaves: Further constraints on the $\mathrm{Li}$ isotopic composition of the continental crust. Chemical Geology, 262: 370-379. 
690

691

692

693

694

695

696

697

698

699

700

701

702

703

704

705

706

707

708

709

710

711

712

Tomascak P.B. (2004) Developments in the understanding and application of lithium isotopes in the Earth and Planetary Sciences. Reviews in Mineralogy \& Geochemistry, 55: 153-195.

Vigier N., Bourdon B., Turner S., Allègre C.J. (2001) Erosion timescales derived from U-decay series measurements in rivers, Earth and Planetary Science Letters, 193: 549-563.

Vigier N., Rollion-Bard C., Spezzaferri S. and Brunet F. (2007) In-situ measurements of Li isotopes in foraminifera. Geochemistry, Geophysics, Geosystems Q01003.

Vigier N., Decarreau A., Millot R., Carignan J., Petit S., France-Lanord C. (2008) Quantifying $\mathrm{Li}$ isotope fractionation during smectite formation and implications for the $\mathrm{Li}$ cycle, Geochimica et Cosmochimica Acta, 72: 780-792.

Vigier N., Gislason S.R., Burton K.W., Millot R., Mokadem F. (2009) The relationship between riverine lithium isotope composition and silicate weathering rates in Iceland. Earth and Planetary Science Letters, 287: 434-441.

White A.F., Blum A.E., Schulz M.S., Vivit D.V., Larsen M., Murphy S.F. (1998) Chemical weathering in a tropical watershed, Luquillo Mountains, Puerto Rico: I. Long-term versus short-term chemical fluxes. Geochimica et Cosmochimica Acta, 62: 209-226.

Wimpenny J., James R.H., Burton K.W., Gannoun A., Mokadem F., Gíslason S.R. (2010) Glacial effects on weathering processes: New insights from the elemental and lithium isotopic composition of West Greenland rivers. Earth and Planetary Science Letters, 290: 427-437.

Zhang L., Chan L.H., Gieskes J.M. (1998) Lithium isotope geochemistry of pore waters from Ocean Drilling Program Sites 918 and 919, Irminger Basin, Geochim. Cosmochim. Acta 62: $2437-2450$. 


\section{Figure captions}

Figure 1

Map showing the sample locations within the Mackenzie River Basin and adjacent basins (Yukon, Stikine, Nass, Skeena and Fraser Basin).

\section{Figure 2}

Inverse correlation of $\mathrm{Li}$ isotopic composition and Li concentration in the dissolved load. In this diagram, the geomorphorphic provinces of the Mackenzie river basin are well distinguished.

\section{Figure 3}

Histogram for Li contribution coming from silicate weathering (\%) in Mackenzie river water samples.

\section{Figure 4}

Histogram of $\mathrm{Li}$ isotopic composition in the dissolved and suspended loads of the Mackenzie rivers. Bedrock values from this study (4 values) and from a compilation of literature data on shale, granite and loess (Teng et al. 2004) are added for comparison. This figure clearly shows the ${ }^{7} \mathrm{Li}$ enrichment of the dissolved phase compared to bedrocks, while suspended sediments and bedrocks are essentially similar.

\section{Figure 5}

Lithium isotopic composition in the suspended sediments of the Mackenzie rivers (main tributaries, Rocky and Mackenzie Mountains, Interior Platform and transition mountain/plain) and glacial till sample (Canadian Shield) as a function of $\mathrm{Na} / \mathrm{Al}$ ratio. This ratio can be seen as a proxy for $\mathrm{Na}$ loss compared to $\mathrm{Al}$, and is therefore a weathering intensity proxy. $\mathrm{Na}$ loss can be attributed either to present day weathering processes or to previous episodes of 
weathering that would have occurred during the geological history of the sedimentary bedrocks.

\section{Figure 6}

Lithium isotopic composition in the dissolved load as a function of $\mathrm{f}_{\mathrm{Li}}$. $\mathrm{f}_{\mathrm{Li}}$ represents the relative mobility of $\mathrm{Li}$ with respect to $\mathrm{Na}$, an element not generally known to be reincorporated into secondary phases. This parameter is defined as the ratio of $\mathrm{Li} / \mathrm{Na}$ in the dissolved load to that in the suspended sediments or, in the case of the Shield province, to the Prosperous Lake moraine. $\mathrm{Na}^{\star}$ denotes here that the $\mathrm{Na}$ concentrations are corrected for atmospheric input and, for a couple of rivers, are corrected for evaporite dissolution according to the results of Millot et al. (2003). Ratios in suspended sediments are considered to represent bedrock ratios. For the Shield rivers, if the glacial till (sample CAN96-31) is used for normalizing the Li/Na data from the shield rivers then $f_{L i}$ values higher that 1 would be obtained for these rivers (not shown on the figure), but lithium isotopic composition and $f_{L i}$ are still correlated.

\section{Figure 7}

Relationship between boron and lithium concentrations in the dissolved load of the rivers sampled in this study. Data from drift aquifers reported by Lemay et al. (2002) have been added to show that the contribution from a groundwater input is likely. Boron data are from Lemarchand and Gaillardet (2006). Boron isotopic data strongly suggest that boron isotopic composition was acquired during reactive transport of boron in shallow groundwaters of relatively high water residence time, and that, boron is therefore a good tracer of the groundwater contribution.

\section{Figure 8}

$\mathrm{Li}$ isotopic composition as a function of Silicate Weathering Rate (Figure 8a) and Silicate Weathering Load (Figure 8b) for the river samples. Silicate weathering rates were calculated 
769 in Millot et al. (2003) based on the inversion of major element concentration and Sr isotope 770 data in the dissolved load, and by Gaillardet et al. (2003) for the Stikine province. In Figure $7718 \mathrm{~b}$, the observed feature is consistent with the idea developed here that the $\mathrm{Li}$ isotopic 772 composition of water in the Mackenzie basin rivers reflects mixing between waters modified 773 by weak (incipient or surficial) weathering (weathering regime $\# 1$ ) and waters dominated by 774 more intense water-rock interactions with the formation of secondary phases in the lowlands 775 of the Mackenzie River Basin (weathering regime \#2). 


\section{Table 1}

779

Lithium isotopic composition $\delta^{7} \mathrm{Li}(\%)$ and concentrations $(\mu \mathrm{mol} / \mathrm{L})$ for rivers waters of the

780

781

782

783

784

785

786

787

788

789

790

791

792

793

794

795

796

797

Mackenzie Basin and the W. Cordillera. Analytical precision for each $\delta^{7} \mathrm{Li}$ measurement is reported in this table and range from 0.1 to $0.3 \%$ o $\left(2 \sigma_{\mathrm{m}}\right)$. As mentioned in the analytical section, the total reproducibility is $\pm 0.5 \% \circ(2 \sigma)$ and has been determined by long-term repeated measurements of a seawater sample (Millot et al. 2004). Surface area $\left(\mathrm{km}^{2}\right)$, river discharge ( $\mathrm{km}^{2} /$ year), runoff (mm/year) and Silicate Weathering Rates (tons $/ \mathrm{km}^{2} / \mathrm{yr}$ and $\mathrm{mg} / \mathrm{L}$ ) have also been added in this table (from Millot et al. 2003).

\section{Table 2}

Lithium isotopic composition $\delta^{7} \mathrm{Li}(\%)$ and concentrations $(\mu \mathrm{g} / \mathrm{g})$ in suspended sediments for rivers from the Mackenzie Basin and adjacent basins draining the Canadian orogenic belt (W. Cordillera). $\mathrm{Na}$ and $\mathrm{Al}$ concentrations are also given in $\mu \mathrm{g} / \mathrm{g}$.

\section{Table 3}

$\delta^{7} \mathrm{Li}(\%)$ and $\mathrm{Li}$ concentrations $(\mu \mathrm{g} / \mathrm{g})$ in sand samples from the Mackenzie River at the river mouth (CAN96-6), as well as in carbonate, blackshales, and two glacial tills sampled on the Canadian Shield. 


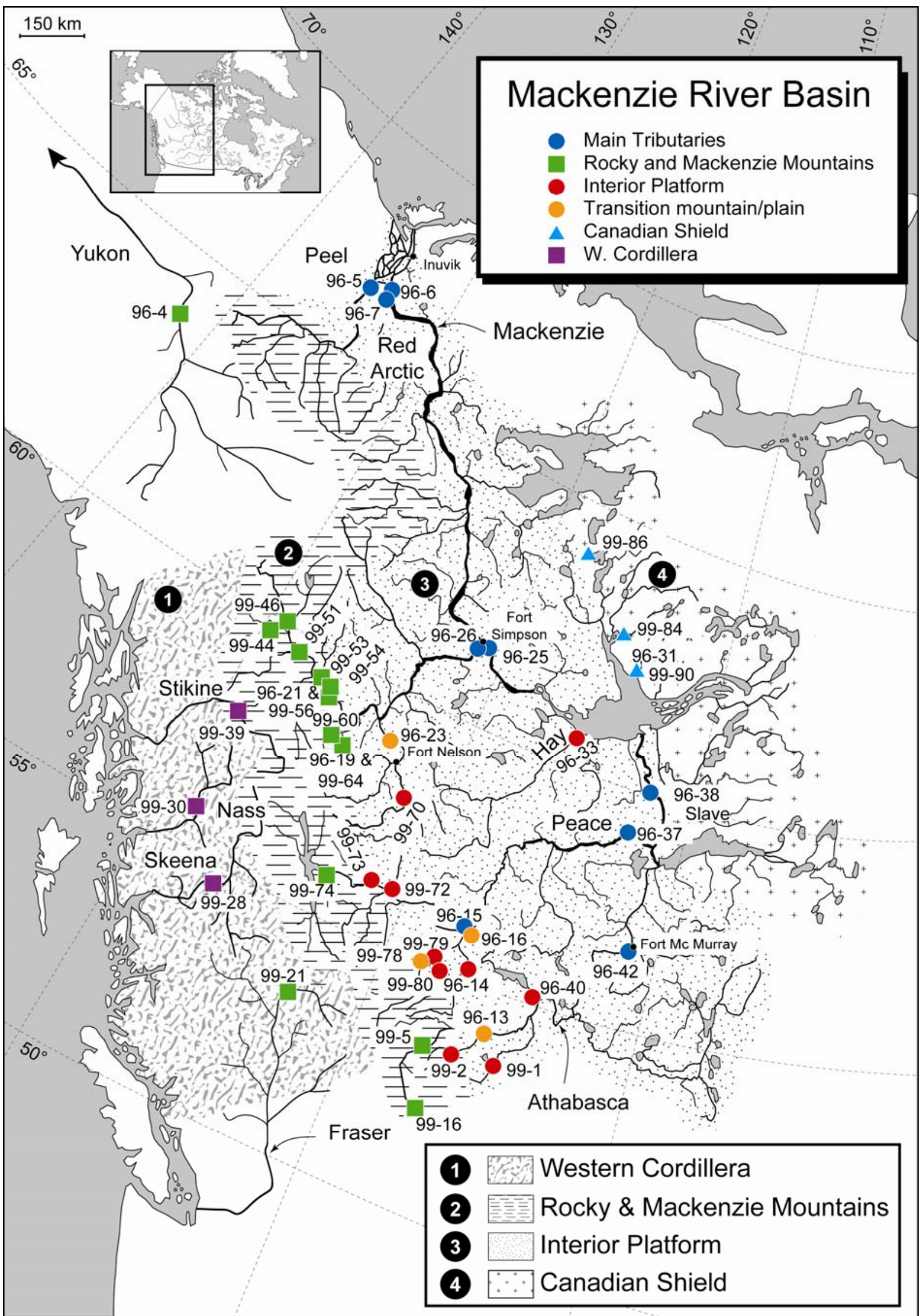




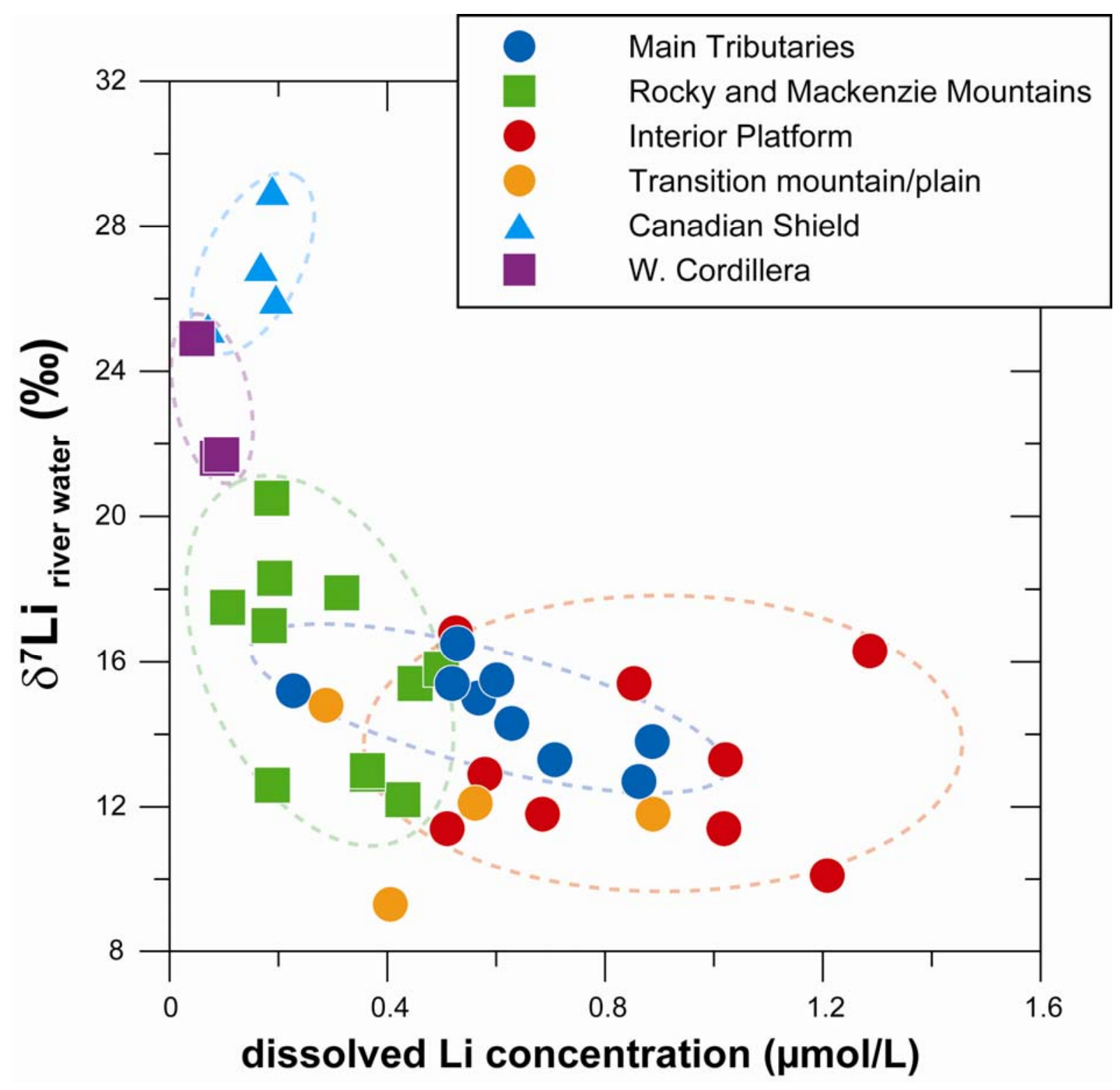

805

806 


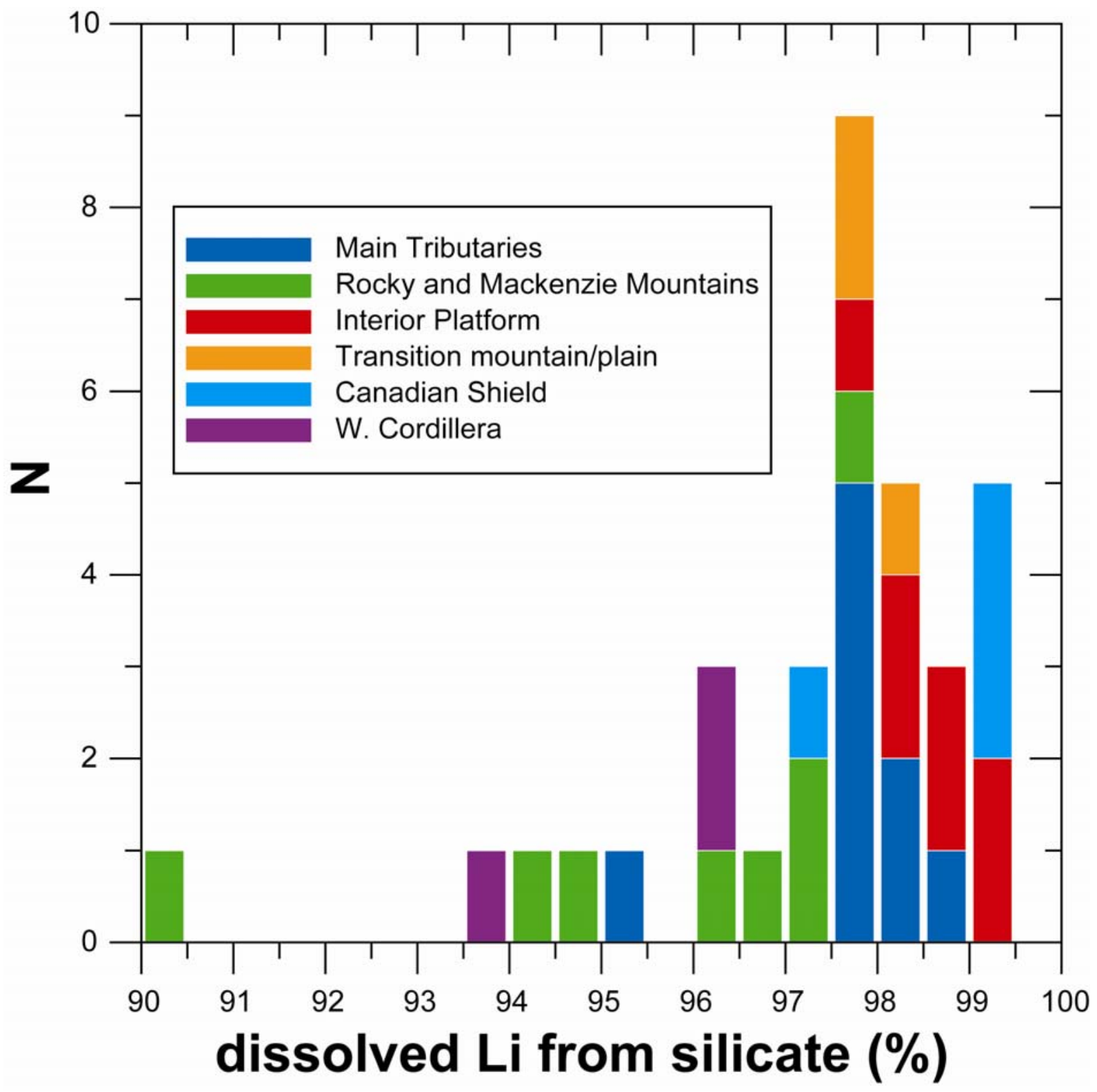


$814 \quad$ Figure 4

815

816

817

818

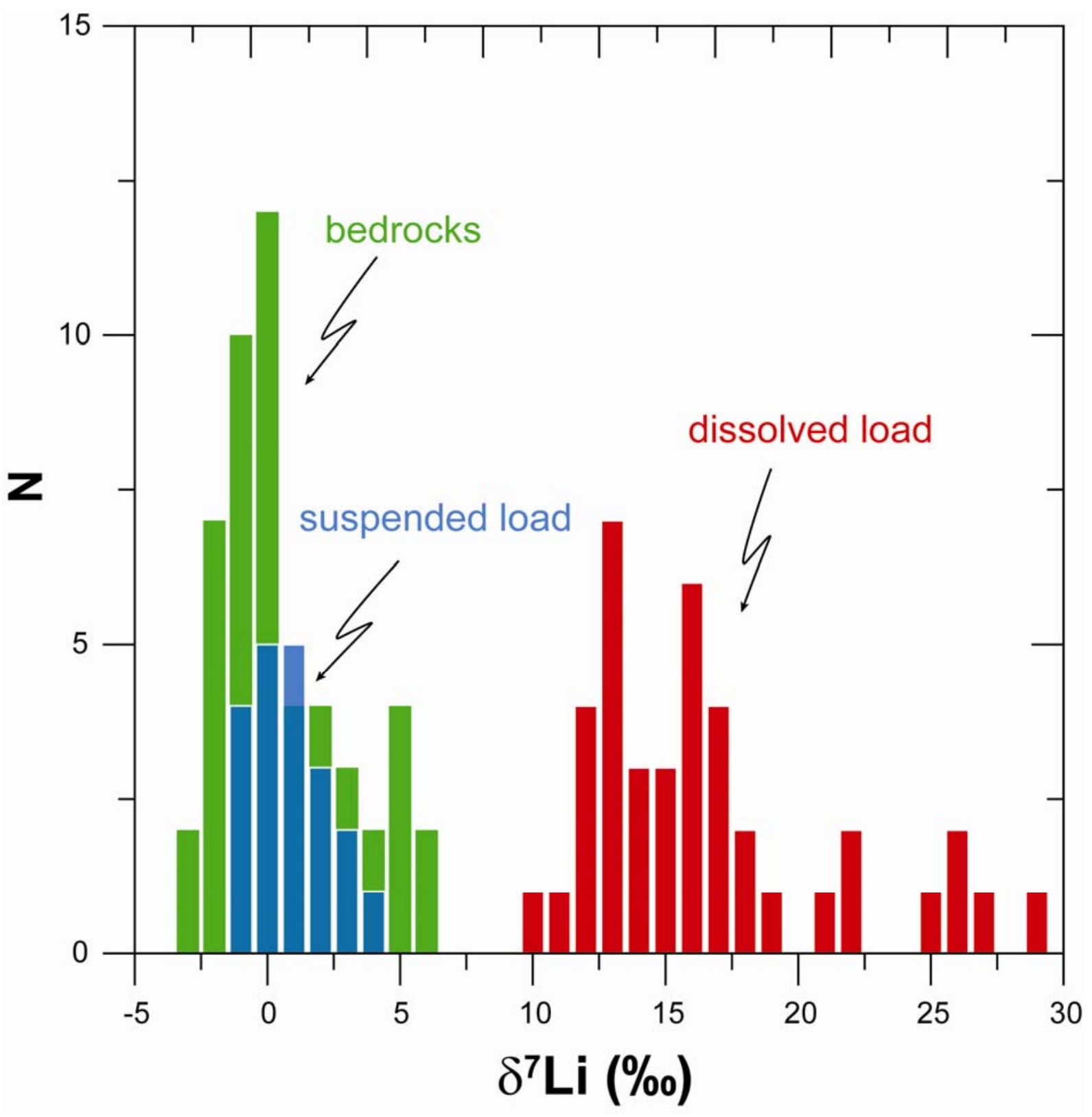




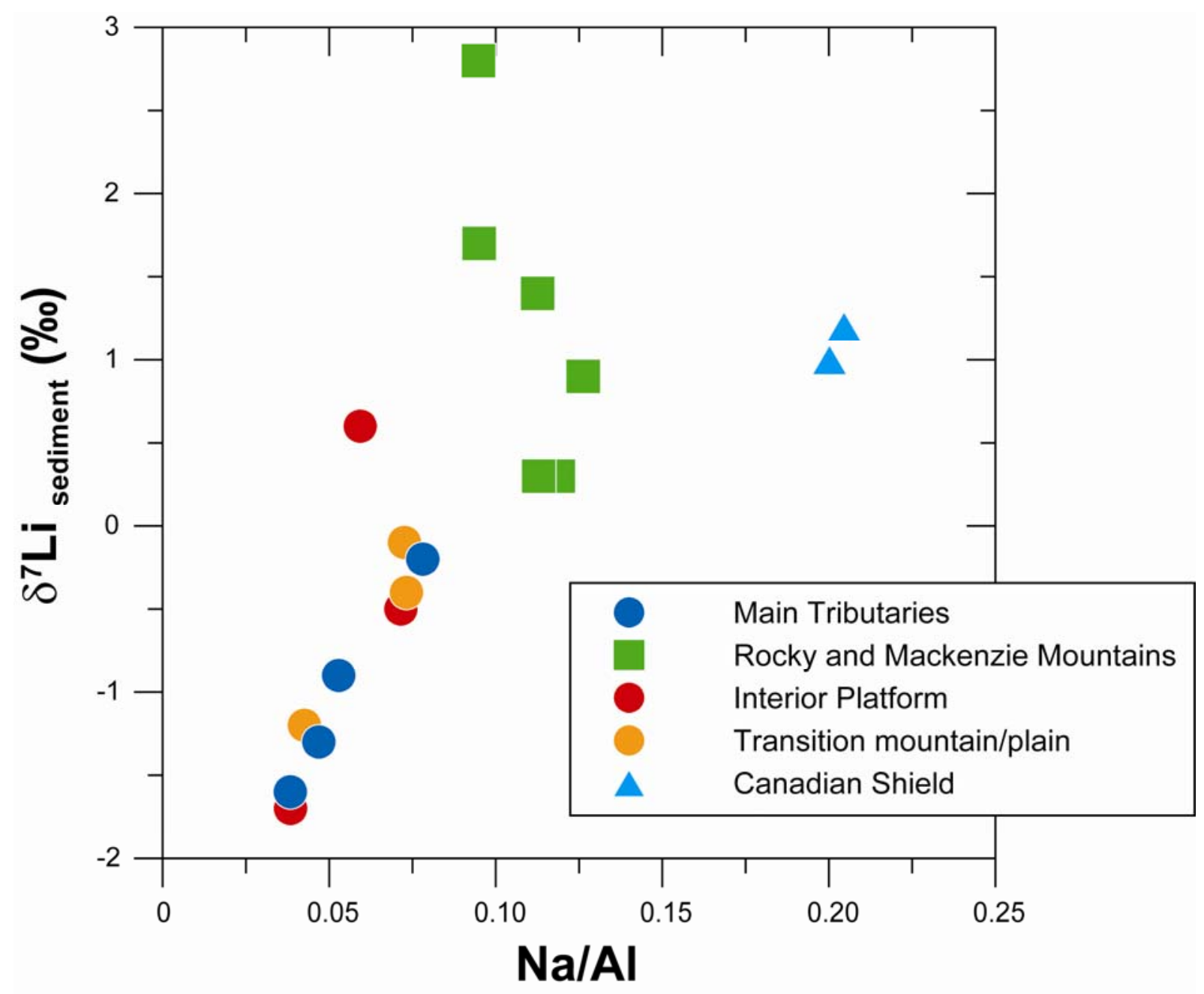




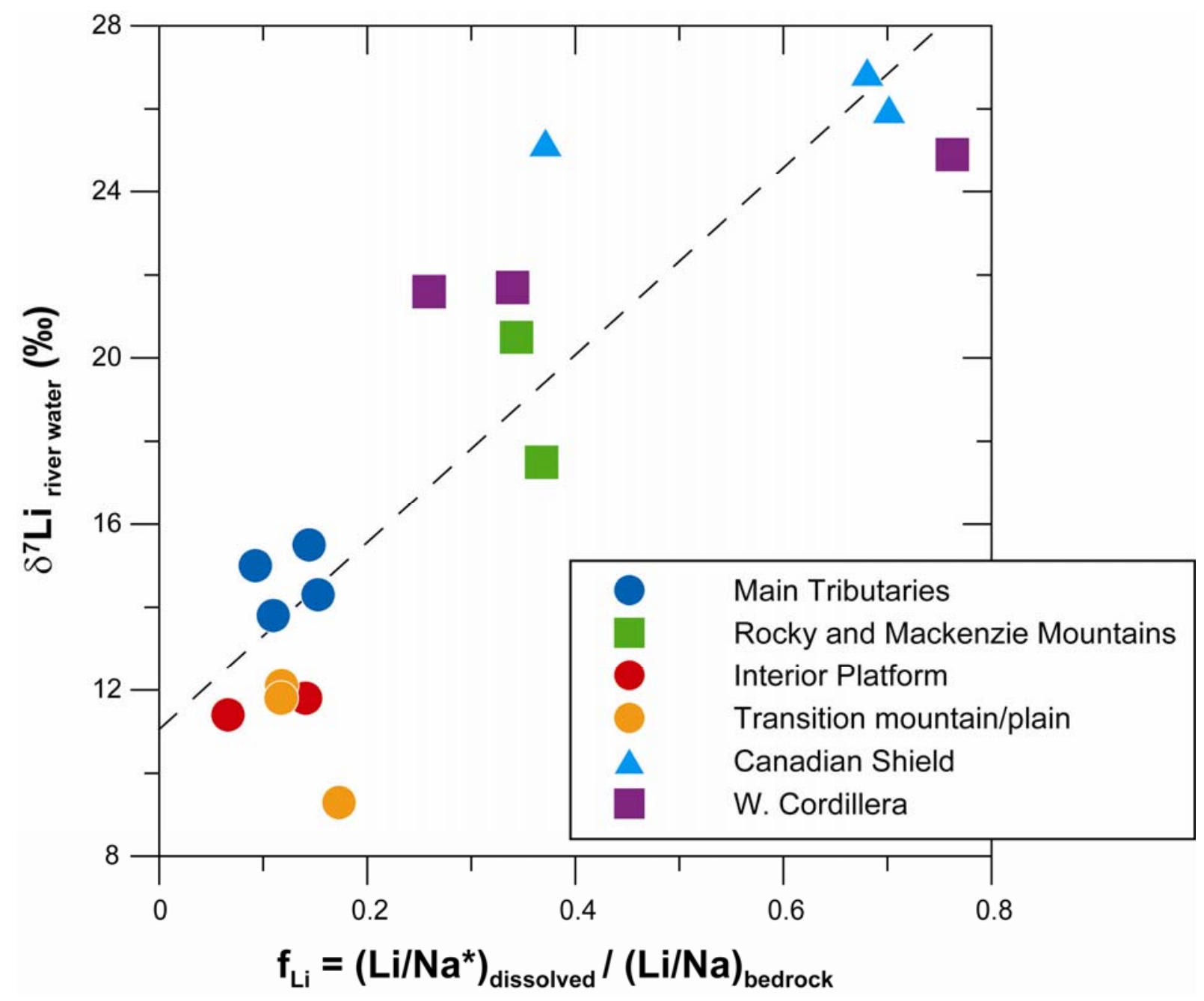




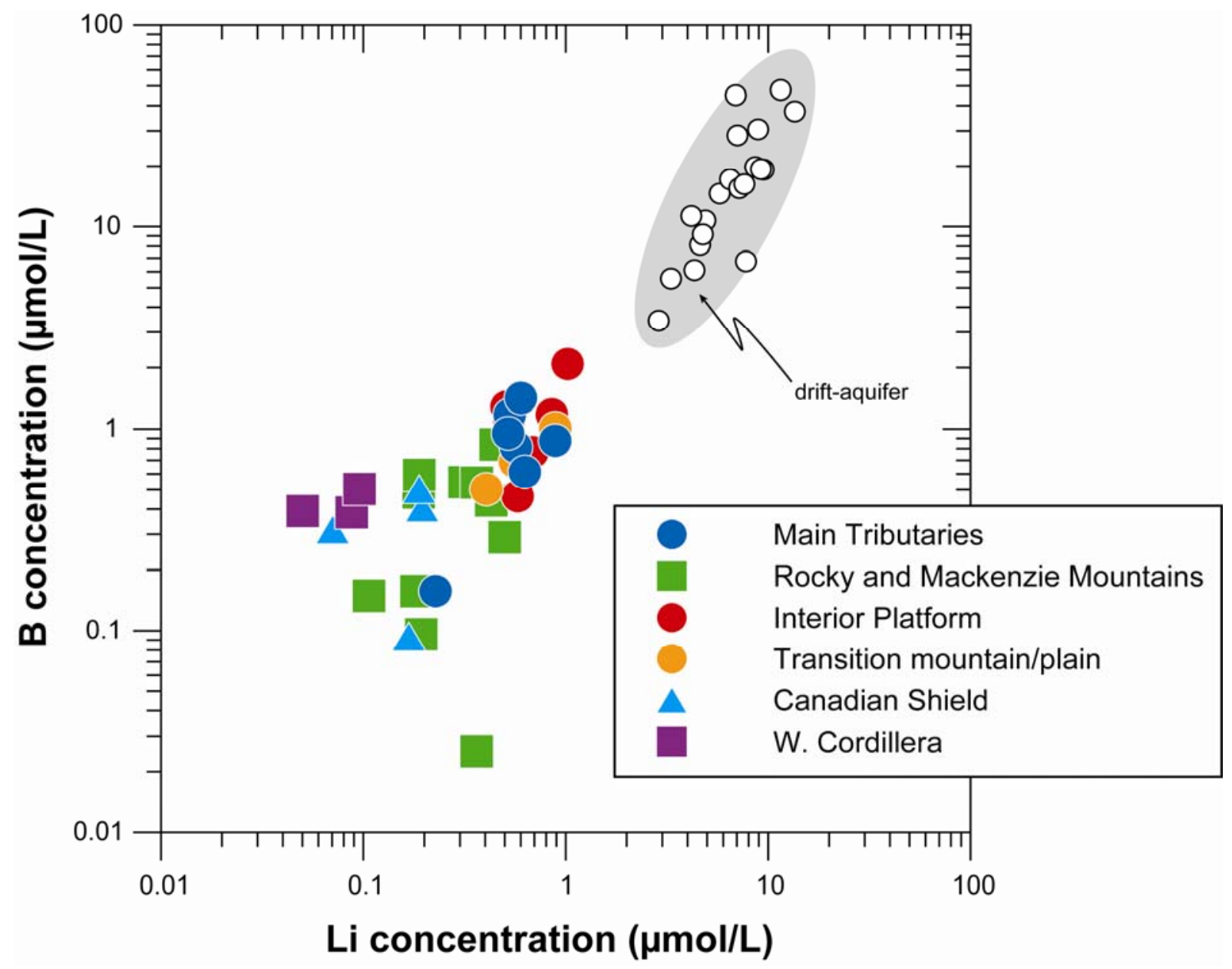




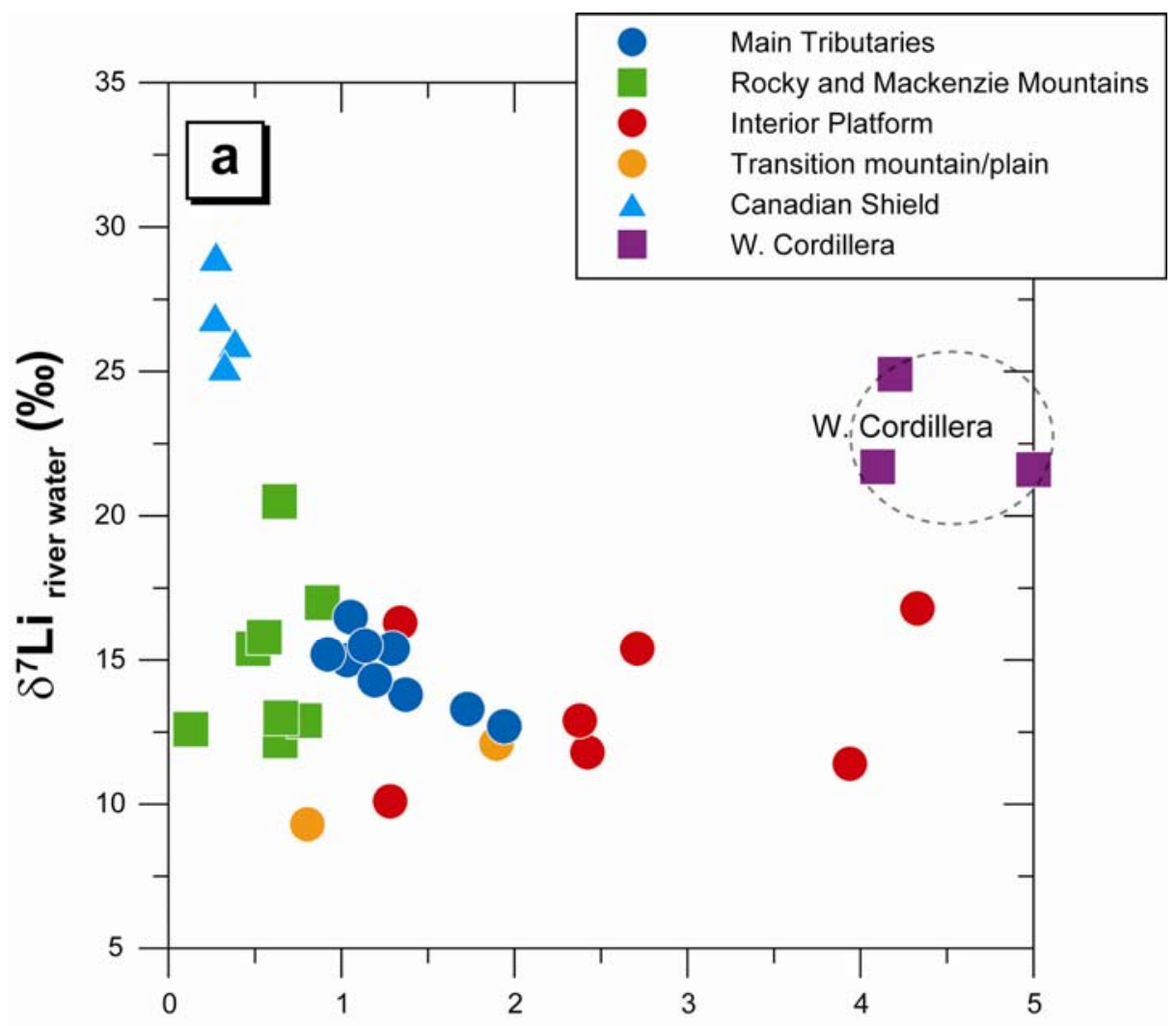

Silicate Weathering Rate (tons $/ \mathrm{km}^{2} / \mathrm{yr}$ )

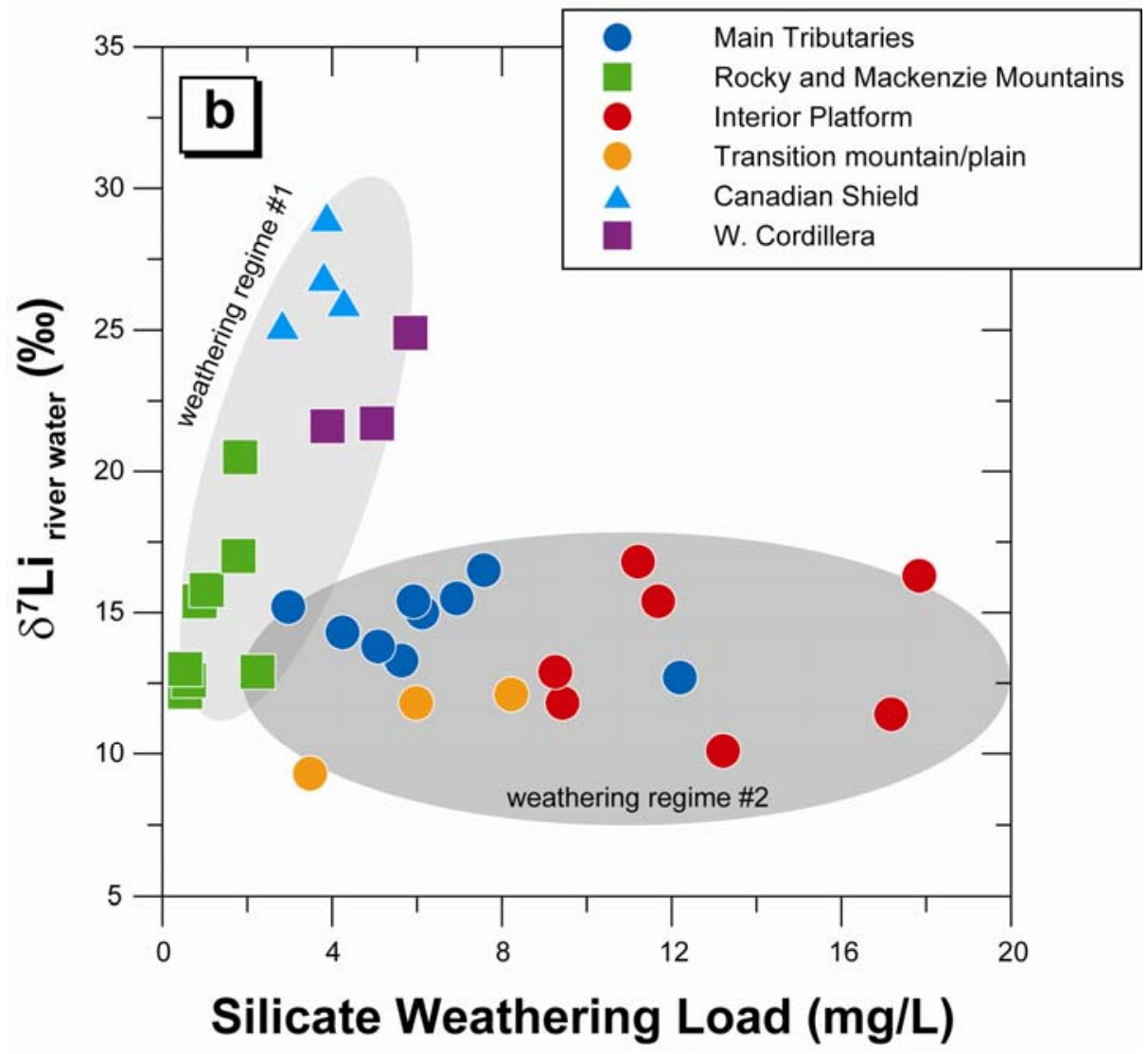




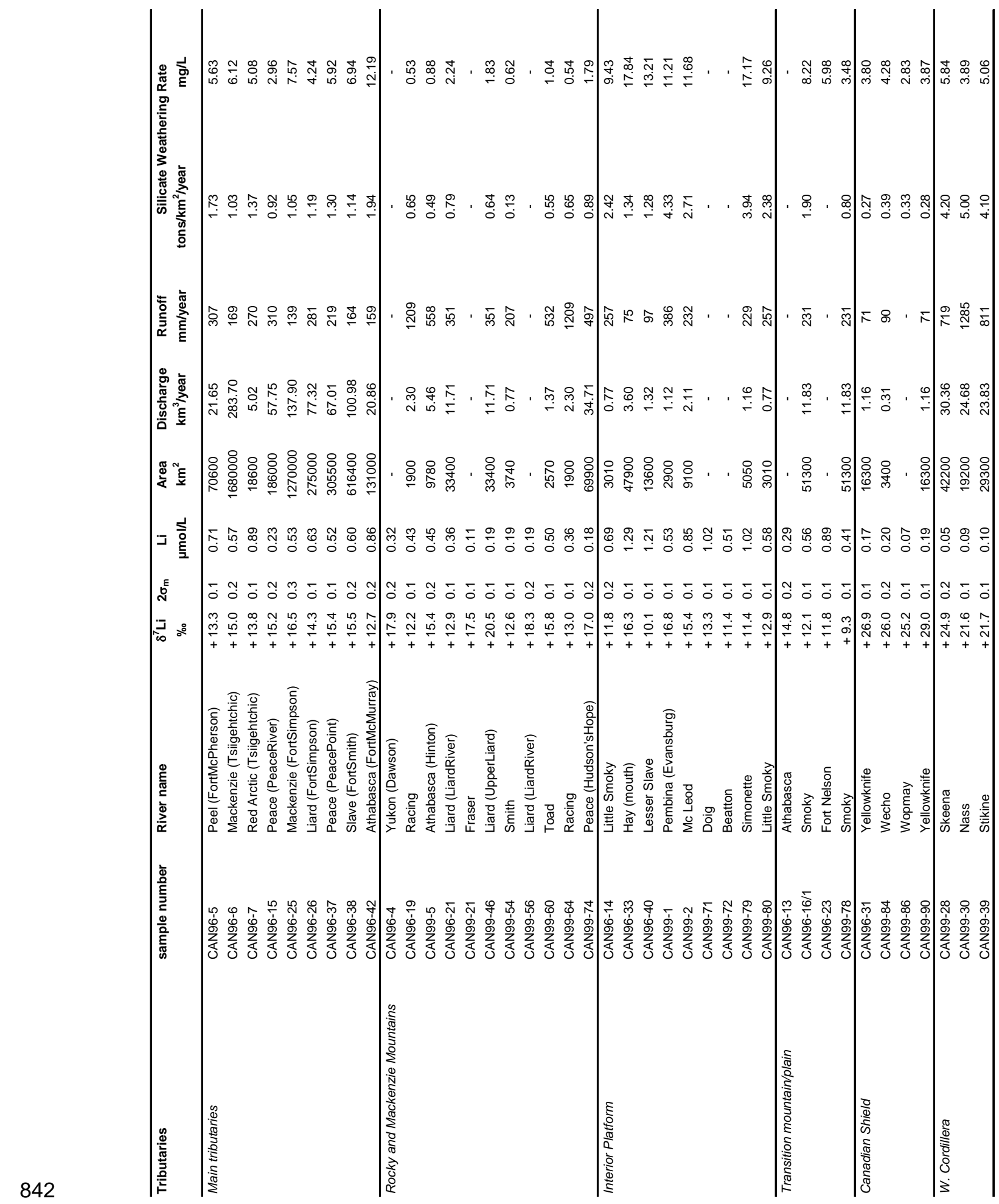


Table 2

846

847

848

849

850

\begin{tabular}{|c|c|c|c|c|c|c|c|}
\hline Tributaries & sample number & River name & $\delta^{7} \mathrm{Li}$ & $2 \sigma_{m}$ & $\mathrm{Li} \mu \mathrm{g} / \mathrm{g}$ & $\mathrm{Na} \mu \mathrm{g} / \mathrm{g}$ & Al $\mu \mathrm{g} / \mathrm{g}$ \\
\hline \multirow[t]{4}{*}{ Main tributaries } & CAN96-6 & Mackenzie (Tsiigehtchic) & -0.9 & 0.2 & 57.8 & 3710 & 70200 \\
\hline & CAN96-7 & Red Arctic (Tsiigehtchic) & -1.6 & 0.1 & 56.8 & 2819 & 73535 \\
\hline & CAN96-26 & Liard (FortSimpson) & -1.3 & 0.2 & 46.1 & 3339 & 71206 \\
\hline & CAN96-38 & Slave (FortSmith) & -0.2 & 0.1 & 41.2 & 5268 & 67447 \\
\hline \multirow[t]{8}{*}{ Rocky and Mackenzie Mountains } & CAN99-5 & Athabasca (Hinton) & +2.6 & 0.2 & 28.9 & - & - \\
\hline & CAN99-16 & Athabasca (Falls) & +3.2 & 0.1 & 19.4 & - & - \\
\hline & CAN99-21 & Fraser & +1.4 & 0.1 & 48.3 & 10387 & 92276 \\
\hline & CAN99-44 & French & +1.7 & 0.2 & 17.9 & 4377 & 46059 \\
\hline & CAN99-46 & Liard (UpperLiard) & +0.9 & 0.2 & 35.1 & 8235 & 65224 \\
\hline & CAN99-51 & Hyland & +0.3 & 0.1 & 44.3 & 8458 & 71206 \\
\hline & CAN99-53 & Coal & +0.3 & 0.1 & 46.2 & 7939 & 70306 \\
\hline & CAN99-57 & Trout & +2.8 & 0.2 & 17.8 & 3042 & 32082 \\
\hline \multirow[t]{3}{*}{ Interior Platform } & CAN96-14 & Little Smoky & -0.5 & 0.1 & 37.8 & 5713 & 79888 \\
\hline & CAN99-72 & Beatton & -1.7 & 0.2 & 51.4 & 2968 & 77294 \\
\hline & CAN99-73 & Halfway & +0.6 & 0.1 & 30.5 & 2968 & 50029 \\
\hline \multirow[t]{3}{*}{ Transition mountain/plain } & CAN96-16 & Smoky & -0.4 & 0.1 & 38.9 & 5565 & 76024 \\
\hline & CAN99-78 & Smoky & -0.1 & 0.1 & 35.3 & 4674 & 64376 \\
\hline & CAN96-23 & Fort Nelson & -1.2 & 0.2 & 56.1 & 3190 & 74965 \\
\hline \multirow[t]{2}{*}{ W. Cordillera } & CAN99-30 & Nass & +1.0 & 0.2 & 37.6 & 14690 & 73376 \\
\hline & CAN99-39 & Stikine & +1.2 & 0.1 & 24.5 & 15358 & 75071 \\
\hline
\end{tabular}

852 
Table 3

854

855

856

857

858

859

860

861

\begin{tabular}{|c|c|c|c|c|c|c|}
\hline Tributaries & Sample type & sample number & sample name/location & $\delta^{7} \mathrm{Li}$ & $2 \sigma_{m}$ & Li $\mu g / g$ \\
\hline Main tributaries & Sand & CAN96-6 & Mackenzie @Tsiigehtchic & -0.5 & 0.1 & 47.4 \\
\hline \multirow[t]{2}{*}{ Rocky and Mackenzie Mountains } & Black Shale & CAN99-5 & Athabasca @Hinton & -1.0 & 0.2 & 29.1 \\
\hline & Carbonate & CAN99-65 & Mc Donald & +7.2 & 0.1 & 1.5 \\
\hline Transition mountain/plain & Black Shale & CAN99-70 & Sikanni Chief & -1.1 & 0.1 & 64.4 \\
\hline \multirow[t]{2}{*}{ Canadian Shield } & Glacial Till & CAN96-31 & Yellowknife & +4.8 & 0.2 & 16.2 \\
\hline & Glacial Till & & Prosperous Lake & +5.2 & 0.2 & 54.6 \\
\hline
\end{tabular}

862

863

864

865

866

867

868

869

870

871

872 